\title{
Dissolved organic matter at the fluvial-marine transition in the Laptev Sea using in situ data and ocean colour remote sensing
}

\author{
Bennet Juhls $^{1}$, Pier Paul Overduin ${ }^{2}$, Jens Hölemann ${ }^{3}$, Martin Hieronymi ${ }^{4}$, Atsushi Matsuoka ${ }^{5}$, Birgit Heim ${ }^{2}$, and \\ Jürgen Fischer ${ }^{1}$ \\ ${ }^{1}$ Institute for Space Sciences, Department of Earth Sciences, Freie Universität Berlin, Berlin, Germany \\ ${ }^{2}$ Alfred Wegener Institute Helmholtz Centre for Polar and Marine Research, Potsdam, Germany \\ ${ }^{3}$ Alfred Wegener Institute Helmholtz Centre for Polar and Marine Research, Bremerhaven, Germany \\ ${ }^{4}$ Institute of Coastal Research, Helmholtz-Zentrum Geesthacht, Geesthacht, Germany \\ ${ }^{5}$ Takuvik Joint International Laboratory, Département de Biologie, Université Laval, Québec City, Canada
}

Correspondence: Bennet Juhls (bjuhls@wew.fu-berlin.de)

Received: 27 February 2019 - Discussion started: 1 March 2019

Revised: 9 June 2019 - Accepted: 17 June 2019 - Published: 11 July 2019

\begin{abstract}
River water is the main source of dissolved organic carbon (DOC) in the Arctic Ocean. DOC plays an important role in the Arctic carbon cycle, and its export from land to sea is expected to increase as ongoing climate change accelerates permafrost thaw. However, transport pathways and transformation of DOC in the land-to-ocean transition are mostly unknown. We collected DOC and $a_{\mathrm{CDOM}}(\lambda)$ samples from 11 expeditions to river, coastal and offshore waters and present a new DOC $-a_{\mathrm{CDOM}}(\lambda)$ model for the fluvial-marine transition zone in the Laptev Sea. The $a_{\mathrm{CDOM}}(\lambda)$ characteristics revealed that the dissolved organic matter (DOM) in samples of this dataset are primarily of terrigenous origin. Observed changes in $a_{\mathrm{CDOM}}(443)$ and its spectral slopes indicate that DOM is modified by microbial and photodegradation. Ocean colour remote sensing (OCRS) provides the absorption coefficient of coloured dissolved organic matter $\left(a_{\mathrm{CDOM}}(\lambda)^{\mathrm{sat}}\right)$ at $\lambda=440$ or $443 \mathrm{~nm}$, which can be used to estimate DOC concentration at high temporal and spatial resolution over large regions. We tested the statistical performance of five OCRS algorithms and evaluated the plausibility of the spatial distribution of derived $a_{\mathrm{CDOM}}(\lambda)^{\text {sat }}$. The OLCI (Sentinel-3 Ocean and Land Colour Instrument) neural network swarm (ONNS) algorithm showed the best performance compared to in situ $a_{\mathrm{CDOM}}(440)\left(r^{2}=0.72\right)$. Additionally, we found ONNS-derived $a_{\mathrm{CDOM}}(440)$, in contrast to other algorithms, to be partly independent of sediment concentration, making ONNS the most suitable $a_{\mathrm{CDOM}}(\lambda)^{\text {sat }}$ algorithm for the Laptev Sea region. The DOC $-a_{\mathrm{CDOM}}(\lambda)$
\end{abstract}

model was applied to ONNS-derived $a_{\mathrm{CDOM}}(440)$, and retrieved DOC concentration maps showed moderate agreement to in situ data $\left(r^{2}=0.53\right)$. The in situ and satelliteretrieved data were offset by up to several days, which may partly explain the weak correlation for this dynamic region. Satellite-derived surface water DOC concentration maps from Medium Resolution Imaging Spectrometer (MERIS) satellite data demonstrate rapid removal of DOC within short time periods in coastal waters of the Laptev Sea, which is likely caused by physical mixing and different types of degradation processes. Using samples from all occurring water types leads to a more robust $\mathrm{DOC}-a_{\mathrm{CDOM}}(\lambda)$ model for the retrievals of DOC in Arctic shelf and river waters.

\section{Introduction}

Large volumes of freshwater $\left(3588 \pm 257 \mathrm{~km}^{3} \mathrm{yr}^{-1}\right.$; Syed et al., 2007) and dissolved organic matter (DOM) (25$36 \mathrm{Tg} \mathrm{C} \mathrm{yr}^{-1}$ ) (Raymond et al., 2007) are discharged by Arctic rivers into the Arctic Ocean (Cooper et al., 2005; Dittmar and Kattner, 2003; Stedmon et al., 2011). Recent studies predict an increase of DOM flux to the Arctic Ocean with continued climate warming and permafrost thawing (Camill, 2005; Freeman et al., 2001; Frey and Smith, 2005). This will lead to a cascade of effects on the physical, chemical and biological environment of Arctic shelf waters (Stedmon et al., 2011). These include an increase of radiative heat trans- 
fer into surface waters, changes in carbon sequestration and reductions of sea-ice extent and thickness (Hill, 2008; Matsuoka et al., 2011).

The Laptev Sea is a wide shelf sea in the eastern Arctic, characterized by fresh surface waters from the Lena River, which delivers around one-fifth $\left(609.5 \pm 59 \mathrm{~km}^{3} \mathrm{yr}^{-1}\right)$ of all river water to the Arctic Ocean (Bauch et al., 2013; Fedorova et al., 2015; Stedmon et al., 2011). River water is the main source of DOM and thus of dissolved organic carbon (DOC) and coloured dissolved organic matter (CDOM) to the Laptev Sea shelf (Cauwet and Sidorov, 1996; GonçalvesAraujo et al., 2015; Kattner et al., 1999; Lobbes et al., 2000; Thibodeau et al., 2014; Vantrepotte et al., 2015). Moreover, the Lena River has the highest peak concentrations of DOC of up to $1600 \mu \mathrm{mol} \mathrm{L}^{-1}$ (Stedmon et al., 2011) of all Arctic rivers. The fate and transformation of DOM as it is discharged to the Arctic Ocean, however, are not well known. Physical and biological processes, such as photodegradation (Gonçalves-Araujo et al., 2015; Helms et al., 2008, 2014; Opsahl and Benner, 1997) and microbial degradation (Benner and Kaiser, 2011; Fasching et al., 2015; Fichot and Benner, 2014; Matsuoka et al., 2012, 2015), as well as mineralization (Kaiser et al., 2017) and flocculation (Asmala et al., 2014; Guo et al., 2007), are responsible for the modification and removal of DOM from river-influenced surface waters. Given the strong seasonality of Lena River runoff (Yang et al., 2002), DOC concentration varies greatly in time and space (Amon et al., 2012; Cauwet and Sidorov, 1996; Raymond et al., 2007; Stedmon et al., 2011). Once exported to the sea, rapid transport of water masses and dislocation of fronts cause rapid changes in concentrations of surface water constituents at any given location.

Therefore, DOC sampling at high temporal and spatial resolutions over long periods is necessary to understand these changes. Discrete in situ sampling of DOC during expeditions provides point measurements at the time of sampling and is complicated by the difficulty of accessing shallow water for ocean-going vessels. The resulting inadequacy of sample coverage in space and time can be overcome by using ocean colour remote sensing (OCRS) data. The absorption coefficient of CDOM $\left(a_{\mathrm{CDOM}}(\lambda)\right)$ at a reference wavelength $\lambda$ (usually $\lambda=443 \mathrm{~nm}$ or $\lambda=440 \mathrm{~nm}$ is used) is an optical property of the water and can also be derived with OCRS during ice and cloud-free periods. Hereinafter, we refer to satellite-derived $a_{\mathrm{CDOM}}(\lambda)$ as $a_{\mathrm{CDOM}}(\lambda)^{\mathrm{sat}}$. CDOM absorbs light in the ultraviolet and visible wavelengths (Green and Blough, 1994) and can be used to estimate DOC concentration (Nelson and Siegel, 2002). Thus, OCRS provides an alternative to discrete water sampling (Matsuoka et al., 2017). DOC concentration maps with high spatial and temporal resolution will improve our understanding of DOC dynamics in fluvial-marine transition zones and better quantify carbon cycling. However, most OCRS retrieval algorithms have focused on optically deep (Case 1) waters, which usually correspond to open ocean where all optical water con- stituents are coupled to chlorophyll concentration (Antoine et al., 2014; Mobley et al., 2004; Morel and Prieur, 1977). Generally, the Laptev Sea coastal to central-shelf waters and Lena River water can be classified as extreme-absorbing and high-scattering waters with high optical complexity (Case 2) (Heim et al., 2014). Algorithms for Case 1 water do not provide reasonable estimates of water constituents in optically complex waters (Antoine et al., 2013). Hieronymi et al. (2017) use a novel algorithm for the retrieval of OCRS products such as $a_{\mathrm{CDOM}}(440)$. This algorithm is specifically designed for a broad range of concentrations of different water constituents including extremely high absorbing waters with $a_{\mathrm{CDOM}}(440)$ of up to $20 \mathrm{~m}^{-1}$.

In order to estimate DOC concentration from $a_{\mathrm{CDOM}}(\lambda)$, a number of empirical relationships between in situ DOC and $a_{\mathrm{CDOM}}(\lambda)$ for Arctic regions (Fichot and Benner, 2011; Gonçalves-Araujo et al., 2015; Mann et al., 2016; Matsuoka et al., 2012; Örek et al., 2013; Spencer et al., 2009; Walker et al., 2013), as well as global (Massicotte et al., 2017), are presented in recent studies. However, the DOC $-a_{\mathrm{CDOM}}(\lambda)$ relationship can vary in different water types and can change between seasons and regions (Mannino et al., 2008; Vantrepotte et al., 2015). Furthermore, existing Arctic datasets of DOC and $a_{\mathrm{CDOM}}(\lambda)$ taken in situ are almost all limited to either offshore, coastal or river waters, so that a DOC $-a_{\mathrm{CDOM}}(\lambda)$ relationship has not been established for the range of water types in Arctic coastal waters. Samples from nearshore waters from Arctic shelves are under-represented in these datasets. In order to obtain synoptic DOC concentration maps that cover the fluvial-marine transition, a relationship valid for a combination of these different water types is required.

Spectral shapes of $a_{\mathrm{CDOM}}(\lambda)$ can provide additional information on the DOM quality and about involved biogeochemical processes that modify the DOM (Carder et al., 1989; Matsuoka et al., 2012; Nelson et al., 2004, 2007). Various studies use the $a_{\mathrm{CDOM}}(\lambda)$ slope in the UV domain (S275-295) as an indicator of the photodegradation history of the $a_{\mathrm{CDOM}}(\lambda)$ (Fichot and Benner, 2012; Helms et al., 2008; Del Vecchio and Blough, 2002). Recent studies presented $a_{\mathrm{CDOM}}(\lambda)$ slopes at different wavelength ranges and their correlation to the DOC specific absorption coefficient $\left(a_{\mathrm{CDOM}}^{*}(\lambda)\right)$ at different wavelengths for the eastern Arctic Ocean (EAO) (Makarewicz et al., 2018: S300-600 to $\left.a_{\mathrm{CDOM}}^{*}(350)\right)$ and the western Arctic Ocean (WAO) (Matsuoka et al., 2012): S350-500 to $a_{\mathrm{CDOM}}^{*}(440)$ ). However, direct comparisons of published studies are made difficult by their use of different reference wavelengths.

In this study, we aim to better understand the transport of organic material from land to sea in the Arctic and improve its detection at regional scale in the Laptev Sea, where the Lena River provides a major source of DOM to the Arctic Ocean. For this, we compile a dataset of DOC and $a_{\mathrm{CDOM}}(\lambda)$ samples collected during multiple expeditions to the Laptev Sea and Lena River region in order to investigate 
the optical characteristics and variability of $a_{\mathrm{CDOM}}(\lambda)$. With this dataset, we develop a new DOC $-a_{\mathrm{CDOM}}(\lambda)$ relationship which we apply to OCRS data in order to estimate DOC concentration from space. We test and evaluate the accuracy of different OCRS algorithms for the fluvial-marine transition zone in the Laptev Sea.

\section{Material and methods}

\subsection{Study area and expeditions}

The in situ data presented in this study are compiled from several, mostly unpublished datasets from Russian-German expeditions to the Lena River and Laptev Sea that took place from 2010 to 2017 (Table 1). Sampling locations of this dataset include large parts of the western and central Laptev Sea shelf, coastal regions around the Lena River Delta and channels of the Lena River (Fig. 1).

All ship- and land-based sampling took place during the ice-free period between the end of June and mid-September. Only one land-based sampling event in the central Lena River Delta took place between the end of May and the end of June, during Lena River peak discharge after the ice breakup. The ship expeditions, which covered offshore shelf waters (NE10, YS11, VB13 and VB14), were conducted on board RV Nikolay Evgenov (NE), RV Jacob Smirnitsky (YS) and RV Viktor Buynitskiy (VB), respectively. For the other ship expeditions, smaller boats were used for sampling in coastal waters or on the Lena River. Water sampling at the research station on Samoylov Island (LD14) was carried out from small boats or from the shore (Fig. 1). Table 1 shows a summary of sampling periods, water types and the sampled parameters of the individual expedition datasets.

\subsection{Hydrographic characteristics and sample processing}

For each sampling location included in this dataset, vertical profiles of the water column temperature and salinity were measured with a conductivity-temperature-depth (CTD) device (Sontek CastAway CTD for LD14, LD15, LD16, Byk17 and a Seabird 19+ for LD10, LD13, NE10, YS11, VB13, VB14 and GA13). In this study, we use the practical salinity unit (psu) to describe salinity. Aboard ships and boats, water samples were taken using Niskin bottles or an UWITEC water sampler at defined depths. Since this study focuses on improving satellite retrievals, only surface water samples (discrete samples from 2 and $5 \mathrm{~m}$ water depth) were included in the compiled dataset. Based on visual examination of the water column characteristics, we also included samples from $10 \mathrm{~m}$ depth wherever a thick homogeneous upper mixed layer was present. During the expedition LD14, water samples were taken from the shore of Samoylov Island at around $0.5 \mathrm{~m}$ depth using $5 \mathrm{~L}$ glass bottles.
Water samples for DOC analysis were filtered through a $0.7 \mu \mathrm{m} \mathrm{GF} / \mathrm{F}$ filter and acidified with $25 \mu \mathrm{L} \mathrm{HCl} \mathrm{Supra-}$ pur $(10 \mathrm{M})$ after sampling. Samples were stored cool and dark for transport. DOC concentrations were measured using high-temperature catalytic oxidation (TOC-VCPH, Shimadzu). Three measurements of each sample were averaged and after each 10 samples, a blank and a standard (Battle-02, Mauri-09 or Super-05 certified reference material from National Laboratory for Environmental Testing, Canada) were measured for quality control.

Samples for $a_{\mathrm{CDOM}}(\lambda)$ analysis were filtered through $0.22 \mu \mathrm{m}$ Millipore GSWP filters (GA13, LD16, Byk17) or $0.7 \mu \mathrm{m}$ Whatman GF/F (LD10, YS11, VB13, VB14, LD14, LD15) after sampling. A $100 \mathrm{~mL}$ filtrate was stored cool and dark in amber glass bottles until further analysis. $a_{\mathrm{CDOM}}(\lambda)$ was measured with a spectrophotometer (SPECORD 200, Analytik Jena) by measuring the absorbance $\left(A_{\lambda}\right)$ at $1 \mathrm{~nm}$ intervals between 200 and $750 \mathrm{~nm}$. Absorption was calculated from the resulting absorbance measurements via

$a_{\mathrm{CDOM}}(\lambda)=\frac{2.303 \cdot A_{\lambda}}{L}$,

where $L$ is the path length (length of cuvette) to calculate the $a_{\mathrm{CDOM}}(\lambda)$. Fresh Milli-Q water was used as reference. The quartz cuvette length varied depending on the expected absorption in the sampled water $(1$ or $5 \mathrm{~cm}$ for river or coastal waters, 5 or $10 \mathrm{~cm}$ for offshore shelf waters). Resulting $a_{\mathrm{CDOM}}(\lambda)$ spectra were corrected for baseline offsets by subtracting the mean absorption between 680 and $700 \mathrm{~nm}$, assuming zero absorption at $>680 \mathrm{~nm}$. We focussed on $a_{\mathrm{CDOM}}$ at $443 \mathrm{~nm}$ since most OCRS algorithms use this wavelength to retrieve $a_{\mathrm{CDOM}}(\lambda)$. This wavelength corresponds to one spectral band of most multispectral satellite sensors. Spectral slopes of $a_{\mathrm{CDOM}}(\lambda)$ were calculated by non-linearly fitting the following equation (Jerlov, 1968; Bricaud et al., 1981):

$a_{\mathrm{CDOM}}(\lambda)=a_{\mathrm{CDOM}}\left(\lambda_{0}\right) \cdot e^{-S\left(\lambda-\lambda_{0}\right)}$,

where $a_{\mathrm{CDOM}}\left(\lambda_{0}\right)$ is the absorption coefficient at reference wavelength $\lambda_{0}$ and $S$ is the spectral slope of $a_{\mathrm{CDOM}}(\lambda)$ for the chosen wavelength range. Spectral slopes of $a_{\mathrm{CDOM}}(\lambda)$ were calculated fitting Eq. (2) for the individual wavelength ranges (275 to $295 \mathrm{~nm}$ for S275-295 and 350 to $500 \mathrm{~nm}$ for S350500). The DOC specific absorption coefficient at $\lambda=440 \mathrm{~nm}$ was calculated with $a_{\mathrm{CDOM}}^{*}(440)=a_{\mathrm{CDOM}}(440) / \mathrm{DOC}$.

\subsection{Satellite data}

In order to monitor spatiotemporal variability of DOC in surface waters and test the applicability of the established DOC $-a_{\text {CDOM }}(\lambda)$ model from this study, we used OCRS. We applied the DOC $-a_{\mathrm{CDOM}}(\lambda)$ model to calculate DOC concentration from satellite-retrieved $a_{\mathrm{CDOM}}(\lambda)$. For this study, we chose the Medium Resolution Imaging Spectrometer (MERIS) because of its high spectral resolution and spectroradiometric quality (Delwart et al., 2007). Many OCRS 
Table 1. Expedition focus regions, years and season. Mean and standard deviation of hydrographic and DOM parameters are listed. The number of samples between DOC and $a_{\mathrm{CDOM}}(443)$ differs for some expeditions, and "n.a." indicates that no DOC measurements were made.

\begin{tabular}{|c|c|c|c|c|c|c|c|c|}
\hline Expedition (code) & $\begin{array}{l}\text { Focus } \\
\text { region }\end{array}$ & Year & Season & $S$ (psu) & $\begin{array}{l}\text { DOC } \\
\left(\mu \mathrm{mol} \mathrm{L}^{-1}\right)\end{array}$ & $\begin{array}{l}a_{\mathrm{CDOM}}(443) \\
\left(\mathrm{m}^{-1}\right)\end{array}$ & $\begin{array}{l}\mathrm{S} 275-295 \\
\left(\mathrm{~nm}^{-1}\right)\end{array}$ & $\begin{array}{l}\mathrm{S} 350-500 \\
\left(\mathrm{~nm}^{-1}\right)\end{array}$ \\
\hline Lena 2010 (LD10) & Coastal & 2010 & Aug & $6.03 \pm 6.59$ & $\begin{array}{l}563 \pm 156 \\
(n=29)^{\mathrm{a}}\end{array}$ & $\begin{array}{l}3.39 \pm 0.27 \\
(n=9)\end{array}$ & $0.0152 \pm 0.0006$ & $0.0167 \pm 0.0019$ \\
\hline $\begin{array}{l}\text { Transdrift XVIII } \\
\text { (NE10) }\end{array}$ & $\begin{array}{l}\text { Central } \\
\text { shelf }\end{array}$ & 2010 & Sep & $23.6 \pm 6.6$ & n.a. & $\begin{array}{l}0.66 \pm 0.46 \\
(n=107)\end{array}$ & $0.0196 \pm 0.0016$ & $0.0175 \pm 0.0028$ \\
\hline $\begin{array}{l}\text { Transdrift XIX } \\
\text { (YS11) }\end{array}$ & $\begin{array}{l}\text { Central } \\
\text { shelf }\end{array}$ & 2011 & $\begin{array}{l}\text { Aug \& } \\
\text { Sep }\end{array}$ & $19.6 \pm 3.6$ & $\begin{array}{l}239 \pm 55 \\
(n=29)\end{array}$ & $\begin{array}{l}0.75 \pm 0.21 \\
(n=26)\end{array}$ & $0.0193 \pm 0.0009$ & $0.0161 \pm 0.0129$ \\
\hline Lena 2013 (LD13) & Lena River & 2013 & $\begin{array}{l}\text { Jul \& } \\
\text { Aug }\end{array}$ & $0.01 \pm 0.05$ & $\begin{array}{l}695 \pm 77 \\
(n=28)^{b}\end{array}$ & $\begin{array}{l}3.25 \pm 0.6 \\
(n=28)\end{array}$ & $0.016 \pm 0.0007$ & $0.0166 \pm 0.0006$ \\
\hline $\begin{array}{l}\text { Gonçalves-Araujo et } \\
\text { al. (2015) (GA 13) }\end{array}$ & Coastal & 2013 & $\begin{array}{l}\text { Jul \& } \\
\text { Aug }\end{array}$ & $14.2 \pm 9.4$ & $\begin{array}{l}398 \pm 155 \\
(n=59)^{\mathrm{d}}\end{array}$ & $\begin{array}{l}1.5 \pm 0.86 \\
(n=42)^{\mathrm{c}}\end{array}$ & $0.017 \pm 0.0015$ & $0.0181 \pm 0.00158$ \\
\hline $\begin{array}{l}\text { Transdrift XXI } \\
\text { (VB13) }\end{array}$ & $\begin{array}{l}\text { Central } \\
\text { shelf }\end{array}$ & 2013 & $\begin{array}{l}\text { Aug \& } \\
\text { Sep }\end{array}$ & $22.6 \pm 6.9$ & n.a. & $\begin{array}{l}0.71 \pm 0.55 \\
(n=19)\end{array}$ & $0.0201 \pm 0.0023$ & $0.0184 \pm 0.0017$ \\
\hline Lena 2014 (LD14) & Lena River & 2014 & $\begin{array}{l}\text { May \& } \\
\text { Jun }\end{array}$ & $0.01 \pm 0.05$ & $\begin{array}{l}1049 \pm 248 \\
(n=50)\end{array}$ & $\begin{array}{l}5.66 \pm 1.85 \\
(n=44)\end{array}$ & $0.0145 \pm 0.001$ & $0.0159 \pm 0.0005$ \\
\hline $\begin{array}{l}\text { Transdrift XXII } \\
\text { (VB14) }\end{array}$ & $\begin{array}{l}\text { Central } \\
\text { shelf }\end{array}$ & 2014 & Sep & $28.3 \pm 2.9$ & $\begin{array}{l}176 \pm 53 \\
(n=46)\end{array}$ & $\begin{array}{l}0.36 \pm 0.19 \\
(n=47)\end{array}$ & $0.0208 \pm 0.0021$ & $0.0196 \pm 0.00164$ \\
\hline Lena 2015 (LD15) & Lena River & 2015 & $\begin{array}{l}\text { Jul \& } \\
\text { Sep }\end{array}$ & $0.01 \pm 0.05$ & n.a. & $\begin{array}{l}2.66 \pm 0.72 \\
(n=12)^{\mathrm{e}}\end{array}$ & $0.0167 \pm 0.0009$ & $0.0166 \pm 0.0006$ \\
\hline Lena 2016 (LD16) & $\begin{array}{l}\text { Lena River } \\
\& \text { coastal }\end{array}$ & 2016 & $\begin{array}{l}\text { Aug \& } \\
\text { Sep }\end{array}$ & $7.3 \pm 9.5$ & $\begin{array}{l}499 \pm 164 \\
(n=17)\end{array}$ & $\begin{array}{l}2.47 \pm 1.22 \\
(n=35)\end{array}$ & $0.0164 \pm 0.001$ & $0.0164 \pm 0.0014$ \\
\hline $\begin{array}{l}\text { Bykovsky } 2017 \\
\text { (Byk17) }\end{array}$ & Coastal & 2017 & $\begin{array}{l}\text { Jun \& } \\
\text { Jul }\end{array}$ & $1.3 \pm 2.2$ & $\begin{array}{l}675 \pm 61 \\
(n=22)\end{array}$ & $\begin{array}{l}2.6 \pm 0.69 \\
(n=22)\end{array}$ & $0.0161 \pm 0.0009$ & $0.019 \pm 0.0013$ \\
\hline
\end{tabular}

${ }^{\mathrm{a}}$ https://doi.org/10.1594/PANGAEA.842220. ${ }^{\mathrm{b}}$ https://doi.org/10.1594/PANGAEA.844928. ${ }^{\mathrm{c}}$ https://doi.org/10.1594/PANGAEA.875748.

${ }^{\mathrm{d}}$ https://doi.org/10.1594/PANGAEA.842221. ${ }^{\mathrm{e}} \mathrm{https} / / / \mathrm{doi}$. org/10.1594/PANGAEA.875754.

Table 2. List of Medium Resolution Imaging Spectrometer (MERIS) scenes used in this study.

\begin{tabular}{lll}
\hline Scene name & Date, time (UTC) & Matchup with \\
\hline MER_RR_1PRBCM20100803_020534_000005942091_00404_44045_0005 & 3 Aug 2010 02:05 & LD10 \\
MER_RR_1PRBCM20100804_031401_000005942091_00419_44060_0004 & 4 Aug 2010 03:14 & LD10 \\
MER_RR_1PRBCM20100805_024241_000005942091_00433_44074_0003 & 5 Aug 2010 02:42 & LD10 \\
MER_RR_1PRBCM20100907_034618_000005942092_00405_44547_0002 & 7 Sep 2010 03:46 & NE10 \\
MER_RR_1PRBCM20100918_030140_000005942093_00061_44704_0006 & 18 Sep 2010 03:01 & NE10 \\
MER_RR_1PRBCM20100919_023010_000005942093_00075_44718_0007 & 19 Sep 2010 02:30 & NE10 \\
MER_RR_1PRBCM20100920_033916_000005942093_00090_44733_0008 & 20 Sep 2010 03:39 & NE10 \\
\hline
\end{tabular}

algorithms were developed specifically for this sensor and are designed for coastal waters. MERIS L1 satellite scenes at reduced resolutions (1 km spatial resolution) were obtained from the MERIS Catalogue and Inventory (MERCI). Scenes with reduced resolution were chosen because of their larger extent and thus better coverage of the in situ data stations. Furthermore, Hu et al. (2012) reported a better signal-tonoise ratio compared to MERIS full-resolution data and recommended the use of MERIS reduced-resolution data. We checked all expedition periods for cloud-free MERIS satellites scenes but only two expeditions from 2010 (LD10 and NE10 ship expeditions) could be used to evaluate the performance of the remote sensing retrieval of the surface water DOC concentration. During those periods, we identified a few scenes with substantial cloud-free data coverage that were acquired during the 2010 expedition periods. Table 2 lists MERIS scenes used in this study. In order to visualize satellite-derived results, we generated mosaic images 


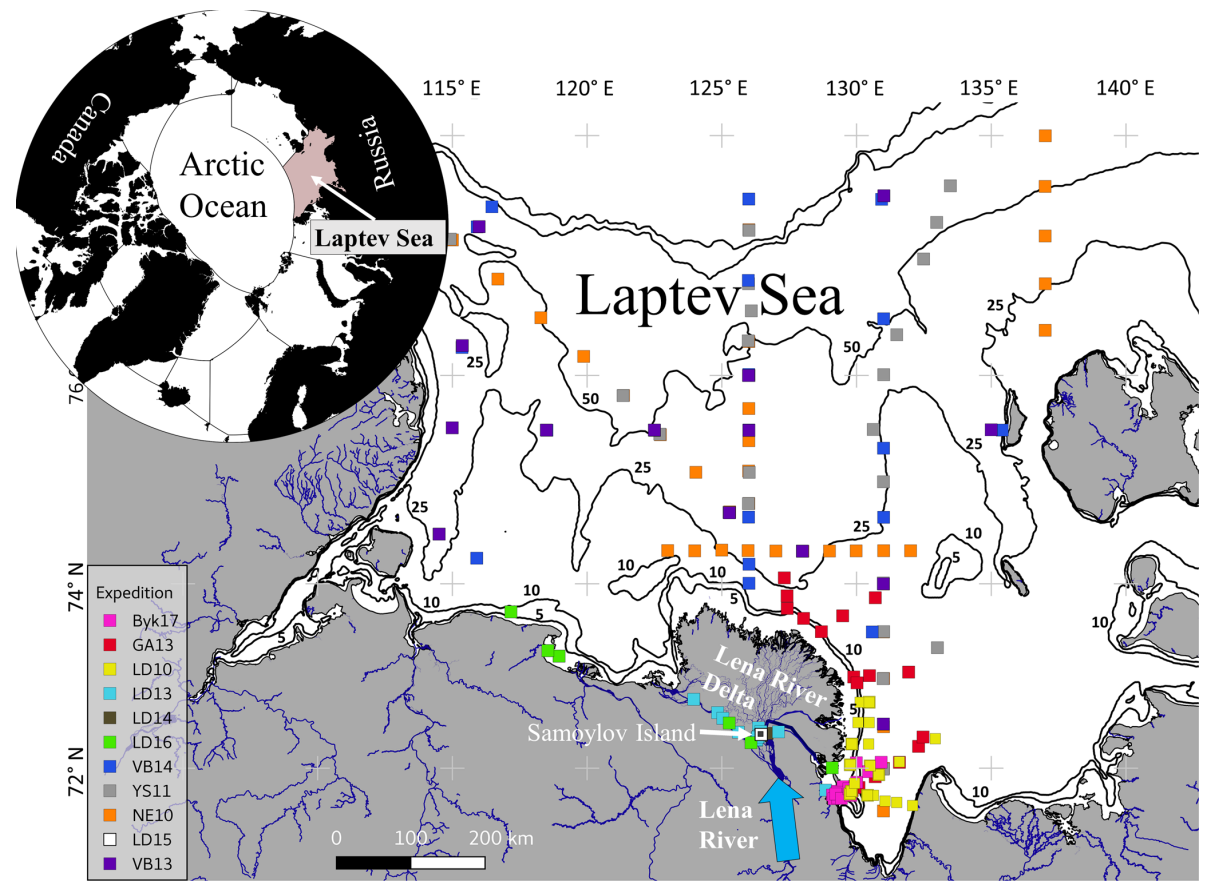

Figure 1. Map of the Laptev Sea and the Lena River Delta region with sample locations from 11 Russian-German expeditions; upper left map shows the Arctic Ocean and the location of the Laptev Sea on the Russian Arctic shelf. Bathymetry is shown by black contour lines and water depth in metres.

containing the average of the overlap from multiple satellite scenes to extend the data coverage between cloud gaps. To compare in situ with satellite data, we used the median of $3 \times 3$ extracted pixel values from each single processed OCRS image. To discuss processes that cause differences between satellite images, we extracted reanalysis surface wind data (four times daily) from the National Centers for Environmental Prediction (NCEP).

Hieronymi et al. (2017) developed the OLCI (Sentinel3 Ocean and Land Colour Instrument) neural network swarm (ONNS) in-water algorithm for the retrieval of OCRS products, among them $a_{\mathrm{CDOM}}(440)$. This algorithm is designed for broad concentration ranges of different water constituents, including extremely high absorbing waters. The algorithm differentiates 13 optical water types (OWTs) and uses specific neural networks (NNs) for each OWT. Every $\mathrm{NN}$ is trained for narrow concentration ranges. The values of $a_{\mathrm{CDOM}}(440)$ used for the training of the NNs are up $20 \mathrm{~m}^{-1}$. The final product is a weighted sum of all NNs depending on OWT membership. The standard atmospheric correction of ONNS, namely the C2RCC (Brockmann et al., 2016), is applied. ONNS makes use of 11 out of the 21 OLCI bands, including the $400 \mathrm{~nm}$ band, which is the only one not delivered by MERIS. In order to retrieve OCRS products with ONNS from MERIS imagery, a band-adaptation NN algorithm is utilized to extrapolate remote sensing reflectance at $400 \mathrm{~nm}$, which is usually provided with an uncertainty $<5 \%$ for these waters (Hieronymi, 2019). Note that the ONNS al- gorithm uses the $a_{\mathrm{CDOM}}(\lambda)$ wavelength of $440 \mathrm{~nm}$, whereas all other algorithms use $443 \mathrm{~nm}$.

Additionally, we tested the following open-source OCRS algorithms: (1) FUB/WeW MERIS Case 2 water properties processor (FUB/WeW) (Schroeder and Schaale, 2005) developed for $a_{\mathrm{CDOM}}(443)$ up to $1 \mathrm{~m}^{-1}$, MERIS Case 2 water algorithm (C2R) (Doerffer and Schiller, 2007) $\left(a_{\mathrm{CDOM}}(443)\right.$ up to $1 \mathrm{~m}^{-1}$ ), which is used for the MERIS third reprocessing of ESA's distributed products, and the Case 2 Regional CoastColour (C2RCC) (Brockmann et al., 2016) with C2RCC $\left(a_{\mathrm{CDOM}}(443)\right.$ up to $\left.1 \mathrm{~m}^{-1}\right)$ and $\mathrm{C} 2 \mathrm{X}\left(a_{\mathrm{CDOM}}(443)\right.$ up to $60 \mathrm{~m}^{-1}$ ). All algorithms used in this study use neural networks trained with databases of radiative transfer simulations or in situ measurements or both to invert the satellite signal into inherent optical water properties such as $a_{\mathrm{CDOM}}(\lambda)^{\mathrm{sat}}$ and concentrations such as total suspended sediment (TSM). In this study, the atmospheric correction from C2RCC (Brockmann et al., 2016) was used to provide atmosphere corrected reflectances for the OCRS algorithms (ONNS, C2R, C2RCC and C2X). For the FUB/WeW algorithm, the atmospheric correction provided by the FUB/WeW processor (Schroeder and Schaale, 2005) was used.

\section{Functions for satellite retrieval evaluation}

In order to evaluate the retrieval of $a_{\mathrm{CDOM}}(\lambda)^{\mathrm{sat}}$ from the tested OCRS algorithms, we used a number of evaluation parameters suggested by Bailey and Werdell (2006) and Mat- 
suoka et al. (2017). Among them, we use the median of satellite to in situ ratio (Rt), the semi-interquartile range (SIQR), the median absolute percent error (MPE) and root mean square error (RMSE). The evaluation parameters are defined as follows:

$\mathrm{Rt}=\operatorname{median}\left(\frac{X_{\text {sat }}}{X_{\text {in situ }}}\right)$,

$\mathrm{SIQR}=\frac{Q_{3}-Q_{1}}{2}$,

MPE $=\operatorname{median}\left(100 \cdot\left|\frac{X_{\text {sat }}-X_{\text {in situ }}}{X_{\text {in situ }}}\right|\right)$,

RMSE $=\sqrt{\frac{\sum_{n=1}^{N}\left[X_{\text {sat }}-X_{\text {in situ }}\right]^{2}}{N}}$,

where $X_{\text {sat }}$ and $X_{\text {in situ }}$ are the satellite-derived and in situ measured $a_{\mathrm{CDOM}}(443)$, respectively. $Q_{1}$ represents the 25 th ratio percentile and $Q_{3}$ represent the 75 th ratio percentile.

\section{Results}

\subsection{Spatial and temporal variability of DOC and CDOM}

To examine variability of DOC and CDOM optical properties along the land-ocean continuum of the Lena-Laptev system, we generated a large dataset that covers spring freshet through late summer from 2010 to 2017 (Table 1). Compared to previously published datasets (Gonçalves-Araujo et al., 2015; Mann et al., 2016; Matsuoka et al., 2012; Walker et al., 2013), this dataset compiles not only samples of one water type but covers river, coastal and offshore waters throughout the most variable portion of the open water season.

To better understand characteristics of DOC and $a_{\mathrm{CDOM}}(\lambda)$ in freshwater-marine waters, the compiled dataset was first classified into three water types according to salinity: (1) fresh river water with salinities from 0 to 0.2 , (2) mesohaline coastal water with salinities from 0.2 to 16 and (3) offshore waters with salinities $>16$.

Overall, DOC concentrations tended to decrease from river to offshore. The same trend was also observed in $a_{\mathrm{CDOM}}(443)$. In river water, DOC concentrations and $a_{\mathrm{CDOM}}(443)$ ranged from 370 to $1315 \mu \mathrm{mol} \mathrm{L}^{-1}$ (median of $779 \mu \mathrm{mol} \mathrm{L}^{-1}$ ) and 1.17 to $7.91 \mathrm{~m}^{-1}$ (median of $3.61 \mathrm{~m}^{-1}$ ), respectively (Fig. 2a and b). DOC concentrations and $a_{\mathrm{CDOM}}(443)$ in coastal waters ranged from 205 to $923 \mu \mathrm{mol} \mathrm{L}^{-1}$ (median of $590 \mu \mathrm{mol} \mathrm{L}^{-1}$ ) and 0.71 to $3.79 \mathrm{~m}^{-1}$ (median of $2.05 \mathrm{~m}^{-1}$ ), respectively. Values in offshore water were the least variable of all three water types, with DOC concentrations from 91 to $606 \mu \mathrm{mol} \mathrm{L}^{-1}$ (median of $234 \mu \mathrm{mol} \mathrm{L}^{-1}$ ) and $a_{\mathrm{CDOM}}(443)$ from 0.077 to $1.86 \mathrm{~m}^{-1}$ (median of $0.5 \mathrm{~m}^{-1}$ ). Generally, observed DOC and $a_{\mathrm{CDOM}}(443)$ values were similar to reported findings from the Lena River and Laptev Sea regions (Amon et al., 2012; Cauwet and Sidorov, 1996; Gonçalves-Araujo et al., 2015; Heim et al., 2014; Raymond et al., 2007; Stedmon et al., 2011).

The spectral UV slope (S275-295) (Fig. 2c) showed similar maximum and median values for river (max. of $0.0184 \mathrm{~nm}^{-1}$, median of $0.0155 \mathrm{~nm}^{-1}$ ) and coastal waters (max. of $0.0192 \mathrm{~nm}^{-1}$, median of $0.0161 \mathrm{~nm}^{-1}$ ). We observed the lowest S275-295 in the Lena River water during the spring freshet at the beginning of June (LD14, Table 1). Offshore water has significantly higher S275-295 values ranging from 0.0158 to $0.0267 \mathrm{~nm}^{-1}$ (median of $0.195 \mathrm{~nm}^{-1}$ ). For river and coastal water, S350-500 showed a similar variability to $\mathbf{S 2 7 5 - 2 9 5}$. The range of offshore water (S350-500), however, showed substantially higher variation and covered a broad range (Fig. 2d).

In contrast to trends in DOC concentrations and $a_{\mathrm{CDOM}}(443), a_{\mathrm{CDOM}}(\lambda)$ spectral slopes in two distinct spectral domains (S275-295 and S350-500) tended to increase from river to offshore (Fig. 2). While the spectral slopes between river (max. of $0.0184 \mathrm{~nm}^{-1}$, median of $0.0155 \mathrm{~nm}^{-1}$ ) and coastal waters (max. of $0.0184 \mathrm{~nm}^{-1}$, median of $0.0158 \mathrm{~nm}^{-1}$ ) were not substantially different, those between the river and offshore were significantly different ( $p$ value $\leq 10^{-8}$ ).

\subsection{CDOM absorption characteristics}

We compared salinity and $a_{\mathrm{CDOM}}(443)$ for the compiled dataset. As in other river-influenced waters, there was a strong linear relationship between $a_{\mathrm{CDOM}}(443)$ and salinity $\left(r^{2}=0.87, n=283\right)$ (Fig. 3), suggesting that physical mixing prevails and plays a role in near-conservative behaviour of $a_{\mathrm{CDOM}}(\lambda)$. For this analysis, only coastal and offshore waters were included since river water was constant in salinity but varied seasonally in $a_{\mathrm{CDOM}}(443)$ (LD14, Table 1). In coastal and offshore waters, $a_{\mathrm{CDOM}}(443)$ decreased gradually with increasing salinity. The observed mixing line is similar to the reported mixing line for Laptev Sea shelf waters from Heim et al. (2014), which was developed using parts of this compiled dataset (LD10 and YS11). The reported relationship from Matsuoka et al. (2012), however, shows generally lower $a_{\mathrm{CDOM}}(443)$ values in waters of the WAO along the salinity gradient. The $\mathrm{S} 350-500$ was very variable along the mixing line. However, low $a_{\mathrm{CDOM}}(443)$ along the mixing line had high S350-500 and higher $a_{\mathrm{CDOM}}(443)$ had low S350-500.

Bulk information, combined use of magnitudes and spectral slopes of CDOM absorption are useful for understanding sources and/or processes involved in the modification of dissolved organic matter, e.g. Fichot and Benner (2012) and Helms et al. (2008). The strongest correlation was observed between $a_{\mathrm{CDOM}}(443)$ and the UV slope of S275-295 (Fig. 4a, Pearson correlation coefficient $(r)$ of -0.84$)$. Similar strong correlations were reported by Fichot and Ben- 

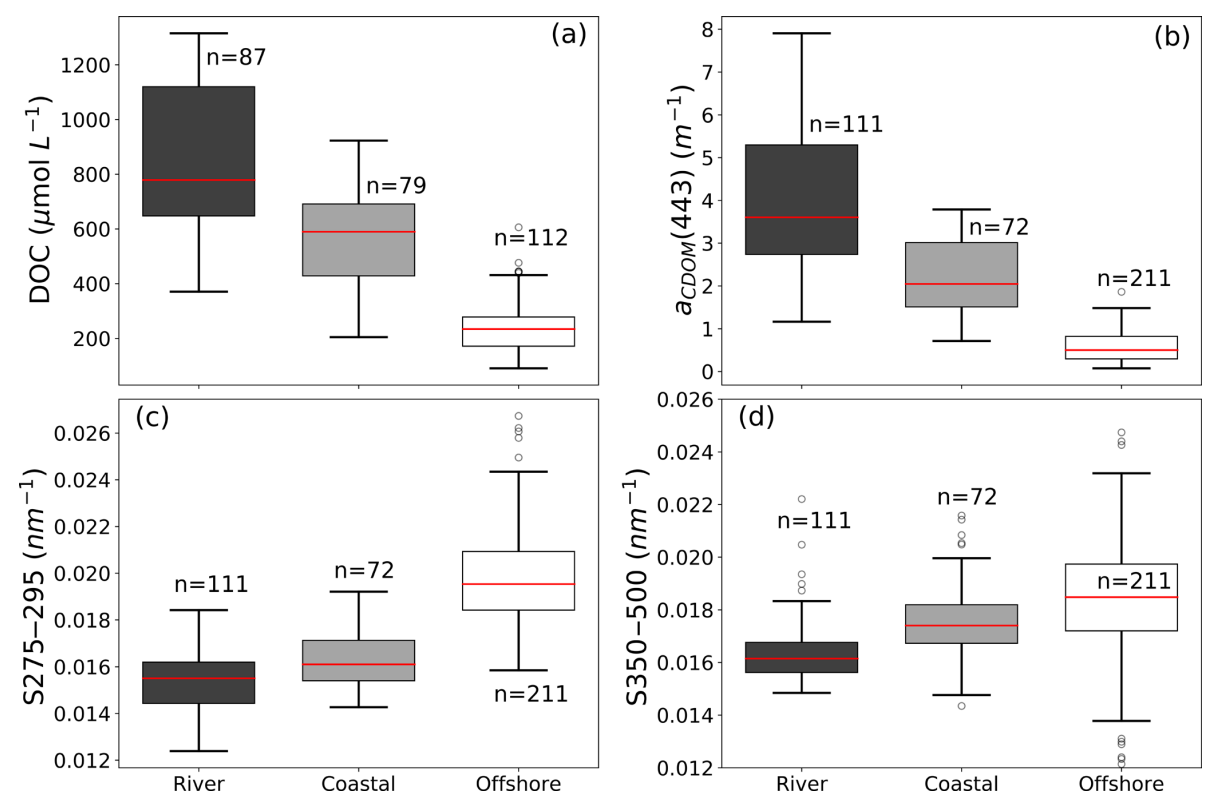

Figure 2. Box plot of (a) DOC concentration, (b) $a_{\mathrm{CDOM}}(443)$, (c) S275-295 and (d) S350-500 for the three water types clustered by salinity (river $<0.2$, coastal $<16$, offshore $>16$ ); the red line indicates median of each water type.

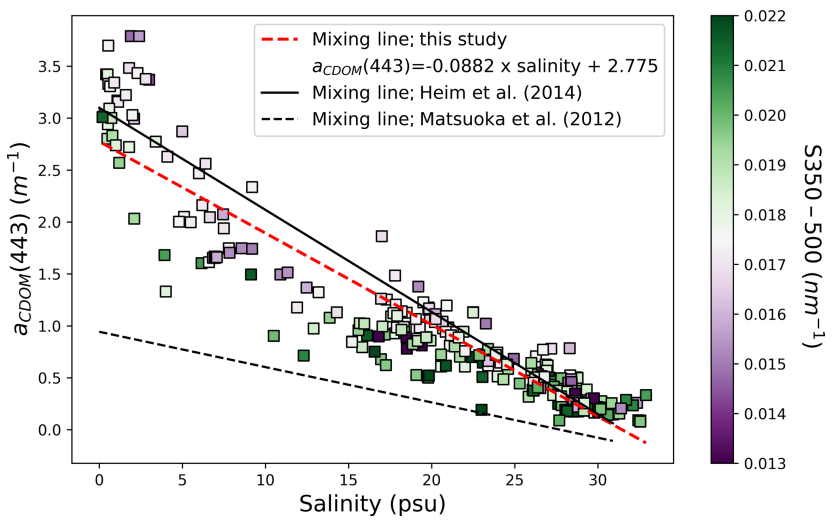

Figure 3. Relationship between $a_{\mathrm{CDOM}}(443)$ and salinity $(n=283$, $\left.r^{2}=0.87\right)$ for all available water sampled from less than $10 \mathrm{~m}$ water depth and a salinity $>0.2$; colour of data points indicates S350 500; red dashed line shows the linear fit representing the mixing line between salinity and $a_{\mathrm{CDOM}}(443)$ within this dataset. The solid black line shows the reported mixing line from Heim et al. (2014) and the dashed black line shows the one from Matsuoka et al. (2012) (adapted to $a_{\mathrm{CDOM}}(443)$ using Eq. 2 and a constant slope of 0.018).

ner (2011) between $a_{\mathrm{CDOM}}(350)$ and S275-295 for coastal waters of the Beaufort Sea in the WAO. Here, we used $a_{\mathrm{CDOM}}(443)$ to make the findings useful for the OCRS community, which usually retrieves $a_{\mathrm{CDOM}}$ at $443 \mathrm{~nm}$. The spectral slope of S350-500 showed moderate correlation with $a_{\mathrm{CDOM}}(443)$ (Fig. $4 \mathrm{~b}, r=-0.54$ ). Furthermore, a high number of S350-500 values were located outside the range of observed S350-500 values for coastal waters of the western Arctic (dashed lines, Fig. 4b).
We observed a moderate correlation between $a_{\mathrm{CDOM}}^{*}(440)$ and S350-500 (Fig. 4c, $r=-0.56$ ). Most samples from this study are located above the $a_{\mathrm{CDOM}}^{*}(440)$ limits of oceanic water reported by Nelson and Siegel (2002), dashed lines in Fig. $4 c$, indicating that water samples from this study are primarily river influenced with higher aromaticity (Granskog et al., 2012; Helms et al., 2008; Weishaar et al., 2003). The reported relationship between $a_{\mathrm{CDOM}}^{*}(440)$ and S350-500 from Matsuoka et al. (2012), solid line in Fig. 4c, deviates strongly in slope of the regression and range of $a_{\mathrm{CDOM}}^{*}(440)$ values from these data from the fluvial-marine transition zone of the Laptev Sea.

Compared to the global CDOM absorption characteristics from Massicotte et al. (2017) (Fig. 4a to c, coloured circles), samples from this study are within the range of freshwaterinfluenced samples with lower salinities and clearly differentiate from high saline oceanic waters.

\subsection{DOC-CDOM relationship}

Generally, retrieval of optical water properties and water constituents such as DOC from satellite data consists of three steps: (1) atmospheric correction of the top-of-atmosphere radiance to the water-leaving or the in-water reflectance, which is needed as input for the OCRS algorithms, (2) the retrieval of $a_{\mathrm{CDOM}}(\lambda)^{\text {sat }}$ from the atmospherically corrected reflectance received by satellite and (3) if $a_{\mathrm{CDOM}}(\lambda)^{\text {sat }}$ is retrieved from OCRS, DOC can be calculated using an in situ DOC versus in situ $a_{\mathrm{CDOM}}(\lambda)$ relationship. The direct validation and evaluation of different atmospheric corrections (1) is beyond the scope of this study. In the following, we present 

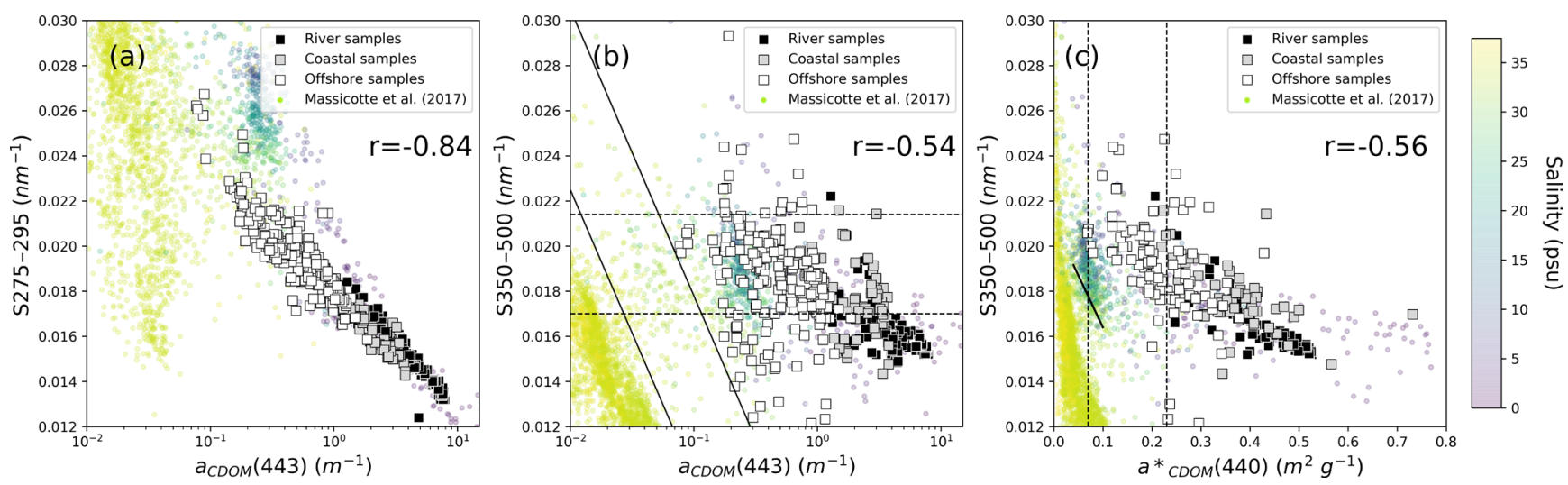

Figure 4. (a) Relationship between $a_{\mathrm{CDOM}}$ (443) and S275-295; (b) $a_{\mathrm{CDOM}}$ (443) vs. S350-500 with $95 \%$ confidence intervals of regressions of western Arctic coastal waters (dashed lines) and for western Arctic oceanic water (solid lines) reported by Matsuoka et al. (2011, 2012), (c) $a^{*} \mathrm{CDOM}(440)$ vs. S350-500 with dashed lines representing the borders of $a^{*} \mathrm{CDOM}(440)$ for oceanic waters reported by Nelson and Siegel (2002), and the solid line shows the reported relationship between $a_{\mathrm{CDOM}}^{*}(440)$ and S350-500 from Matsuoka et al. (2012). Circles show global data from Massicotte et al. (2017) where colours indicate the salinity.

a new regional DOC $-a_{\mathrm{CDOM}}(\lambda)$ relationship (3) from our compiled in situ dataset.

We observed a strong relationship between $a_{\mathrm{CDOM}}(443)$ and DOC concentration for all water samples including river to marine waters (Fig. 5). Overall, 1 order of magnitude variation in DOC corresponded to more than 2 orders of magnitude of variation in $a_{\mathrm{CDOM}}(443)$ for this sample set and corresponded to the range from moderately absorbing waters $\left(0.1-1.0 \mathrm{~m}^{-1}\right)$ to highly absorbing waters $\left(>1.0 \mathrm{~m}^{-1}\right)$. After testing different regression models, the best fit was derived with a power function (Eq. 7, red line in Fig. 5):

$\operatorname{DOC}\left(\mu \mathrm{molL} \mathrm{L}^{-1}\right)=10^{2.525} \cdot a_{\mathrm{CDOM}}(443)^{0.659}$.

The agreement between model and data $\left(r^{2}=0.96, n=227\right)$ allowed estimation of DOC by $a_{\mathrm{CDOM}}(443)$ within a $50 \%$ error range. The highest deviations from the fitted line corresponded to the transition zone between offshore shelf waters and coastal waters $\left(a_{\mathrm{CDOM}}(443)\right.$ of $\left.0.5-1.5 \mathrm{~m}^{-1}\right)$ and to the very low end of the $a_{\mathrm{CDOM}}(443)$ range $\left(<0.5 \mathrm{~m}^{-1}\right)$. It is noted that the fitting model of this dataset using only offshore or river water samples would result in a lower slope (exponent of 0.617 for coastal and offshore water, 0.606 for offshore water only) in the resulting DOC- $a_{\mathrm{CDOM}}(443)$ model. Including coastal and river samples substantially increased the slope of the fit, which results in higher DOC estimates for high $a_{\mathrm{CDOM}}(443)$. The reported relationship from Mann et al. (2016) is similar for high- $a_{\mathrm{CDOM}}(443)$ river water but deviates for low- $a_{\mathrm{CDOM}}(443)$ river water and coastal and offshore water. The model presented by Matsuoka et al. (2017) (blue line in Fig. 5) has a lower slope and results in the highest differences for DOC estimation at high $a_{\mathrm{CDOM}}(443)$.

Model coefficients for other selected $a_{\mathrm{CDOM}}(\lambda)$ wavelengths are presented in Table A1 (Appendix A). Furthermore, the relationship between S275-295 and DOC had

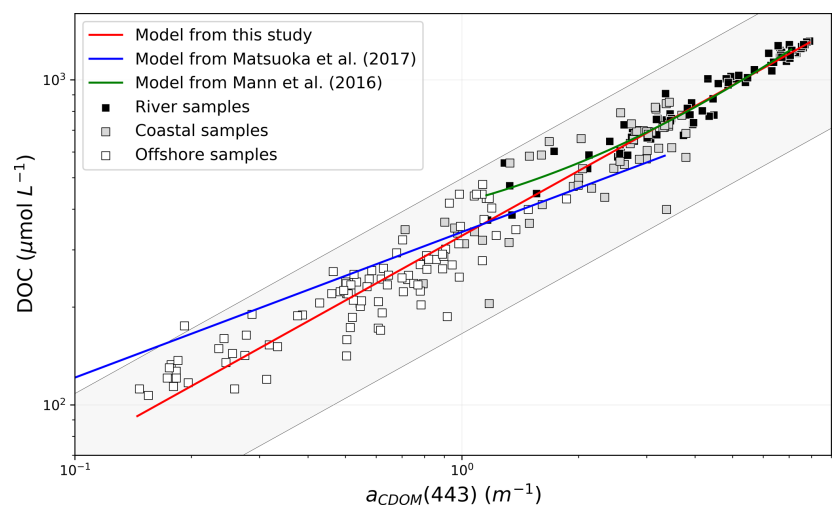

Figure 5. Relationship between $a_{\mathrm{CDOM}}(443)$ and DOC $\left(r^{2}=\right.$ 0.96). Red line shows the derived model from this dataset. The blue line shows the relationship from Matsuoka et al. (2017) for a panArctic dataset for offshore and coastal waters. The green line shows the relationship for Lena River water from Mann et al. (2016). The filled grey area shows the $50 \%$ error range. Note that the axes are displayed in log scale.

a slightly weaker correlation with DOC $\left(r^{2}=0.92\right)$ than $a_{\mathrm{CDOM}}(443)$.

\subsection{Satellite-retrieved CDOM}

To estimate the surface water DOC concentration with the presented DOC- $a_{\mathrm{CDOM}}(\lambda)$ model (Eq. 7, Fig. 5) and generate DOC concentration maps for large scales, we need a robust and accurate retrieval of $a_{\mathrm{CDOM}}(\lambda)^{\mathrm{sat}}$.

We examined the performance of five OCRS algorithms in terms of $a_{\mathrm{CDOM}}(443)^{\text {sat }}$ retrieval using Eqs. (3) to (6). For this purpose, $a_{\mathrm{CDOM}}(443)^{\text {sat }}$ retrievals were compared to in situ data from within $10 \mathrm{~d}$ of the satellite retrievals. Our comparisons showed highly varying results (Figs. 6, B1 in Ap- 

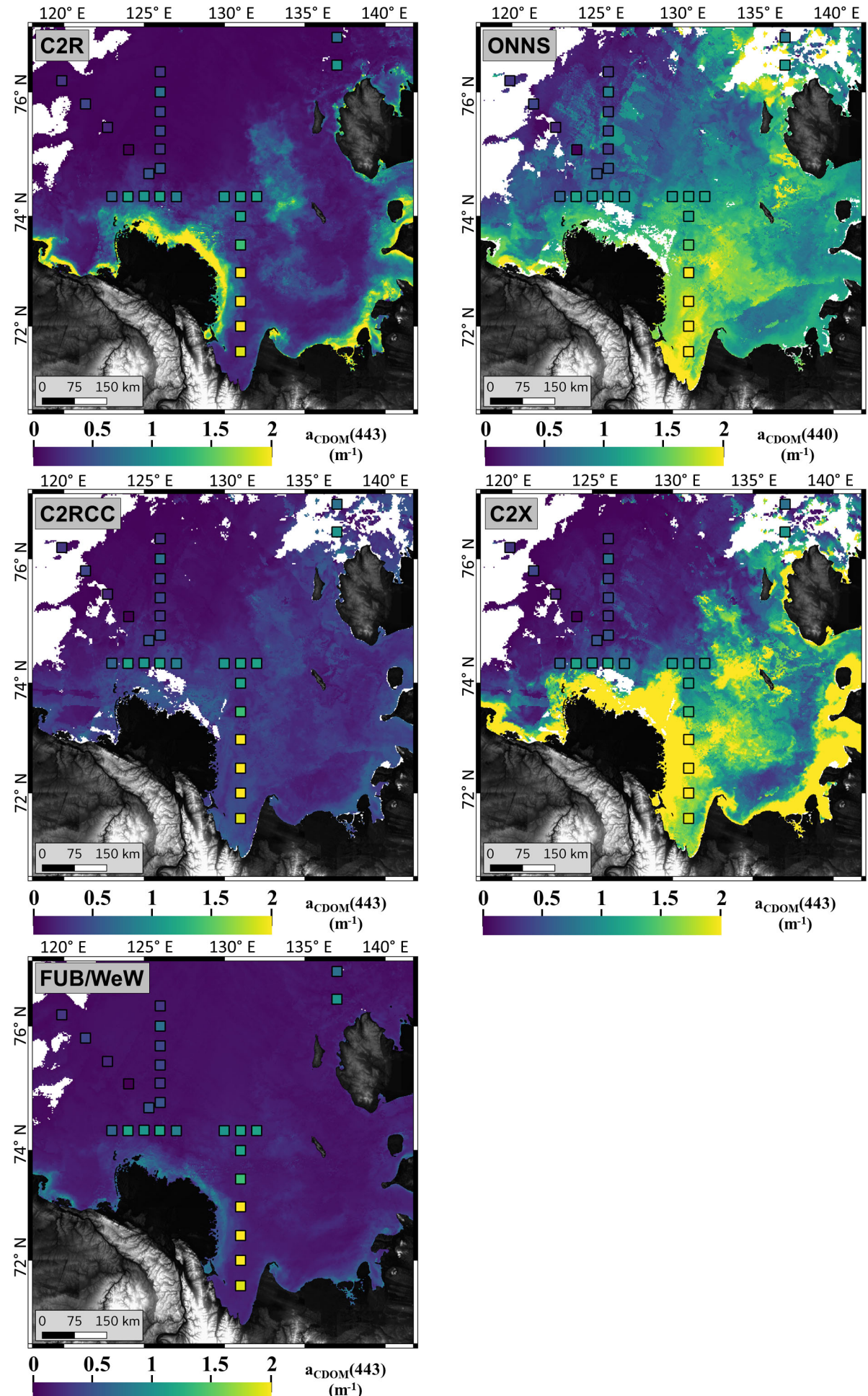

Figure 6. Surface water $a_{\mathrm{CDOM}}(\lambda)^{\text {sat }}$ from MERIS mosaic from five scenes from September 2010 (scenes listed in Table 2) for all tested OCRS algorithms (C2R, ONNS, C2RCC, C2X, FUB/WeW). Squares show in situ $a_{\mathrm{CDOM}}(443)\left(a_{\mathrm{CDOM}}(440)\right.$ for ONNS) with colours according to the same colour scale as satellite data. 
Table 3. Performance of tested OCRS algorithms for $a_{\mathrm{CDOM}}(\lambda)^{\text {sat }}$ with in situ $a_{\mathrm{CDOM}}(443)$ or $a_{\mathrm{CDOM}}(440)$. Note that not all OCRS algorithms are developed for the highly absorbing waters (high $a_{\mathrm{CDOM}}(\lambda)$ ) found in the Arctic coastal region.

\begin{tabular}{lrrrrrrrr}
\hline OCRS algorithm & $n$ & slope & intercept & $r^{2}$ & Rt & SIQR & $\%$ MPE & RMSE \\
\hline ONNS & 34 & 0.571 & 0.493 & 0.716 & 0.679 & 0.217 & 58.39 & 0.436 \\
C2R & 34 & 0.157 & 0.087 & 0.329 & 3.23 & 0.075 & 223.38 & 0.277 \\
C2RCC & 34 & 0.048 & 0.157 & 0.271 & 3.23 & 0.093 & 223.05 & 0.097 \\
C2X & 34 & 1.023 & -0.212 & 0.652 & 1.09 & 0.224 & 100.0 & 0.919 \\
FUB/WeW & 34 & 0.178 & 0.013 & 0.545 & 3.76 & 0.057 & 276.49 & 0.2 \\
\hline
\end{tabular}

pendix B, Table 3) and strong under- or overestimation of $a_{\mathrm{CDOM}}(\lambda)^{\text {sat }}$. Particularly in turbulent coastal waters, comparison of $a_{\mathrm{CDOM}}(443)^{\text {sat }}$ with in situ $a_{\mathrm{CDOM}}(443)$ is challenging, given the fact that the magnitude of CDOM absorption can vary greatly over a short time for the location of a given pixel. ONNS-derived $a_{\mathrm{CDOM}}(\lambda)^{\text {sat }}$ performed best $\left(r^{2}=0.716\right.$, Rt of 0.679 , SIQR of 0.217 , \% MPE of 58.39, RMSE of 0.436). The C2X algorithm performed similarly with a lower $r^{2}(0.65)$ and substantially higher \%MPE (100.0) and RMSE (0.919). In addition to the comparison with in situ data, we evaluated the plausibility of the resulting spatial distributions and observed extremely high C2Xderived $a_{\mathrm{CDOM}}(443)^{\text {sat }}$ values in the Lena River mouth (up to $10 \mathrm{~m}^{-1}$ ). Such values of $a_{\mathrm{CDOM}}(443)$ were not confirmed by any reported in situ data. ONNS-derived $a_{\mathrm{CDOM}}(443)^{\mathrm{sat}}$ showed values which are in the range of in situ observed $a_{\mathrm{CDOM}}(443)$. Other algorithms show clear underestimations of $a_{\mathrm{CDOM}}(443)^{\mathrm{sat}}$ compared to in situ data (Fig. B1). Thus, ONNS was the only algorithm that produced $a_{\mathrm{CDOM}}(\lambda)$ values in a similar range to in situ measured $a_{\mathrm{CDOM}}(440)$.

\subsection{Surface water DOC concentrations in coastal waters of the Laptev Sea}

Using the presented DOC $-a_{\mathrm{CDOM}}(\lambda)$ model, we generated satellite-derived images of surface water DOC concentrations for the Lena-Laptev region. All scenes were processed with the ONNS algorithm, and $a_{\mathrm{CDOM}}(440)$ was averaged for each mosaic. DOC concentrations for two mosaics (Fig. 7b, d) were calculated by using the adapted model from Eq. (7) with coefficients for $a_{\mathrm{CDOM}}(440)$ instead of $a_{\mathrm{CDOM}}(443)$. The mean time difference between the two mosaics is $31 \mathrm{~d}$. The DOC mosaic from early August 2010 (Fig. 7b) shows high DOC concentrations over large areas in the eastern Laptev Sea. Concentrations $\left(>600 \mu \mathrm{mol} \mathrm{L}^{-1}\right.$ ) were highest in Buor-Khaya Bay east of the Lena River Delta where the Lena River exports most of its water. The plume of the Lena River with high DOC concentrations $\left(\sim 500 \mu \mathrm{mol} \mathrm{L}^{-1}\right)$ had propagated northeastward in this scene. The DOC mosaic from September 2010 (Fig. 7d) shows generally lower DOC concentrations compared to the earlier scene. Highest concentrations were found in the coastal areas in Buor-Khaya Bay (east of the Lena River Delta) and around the Olenek River Delta (west of the Lena River Delta). While ONNS per- forms well in river-influenced waters, we note that DOC concentrations at the northern edge can be influenced by cloud masking (patches of high DOC concentrations shown in the northeast corner of Fig. 7d).

Both quasi-true colour satellite images (Fig. 7a, c) show sediment-rich, strongly backscattering waters around the Lena River Delta resulting from fluvial transport. In the satellite image from 7 September 2010 (Fig. 7c), there is also a large strongly backscattering area in the eastern Laptev Sea, where resuspension events in shallow water (5-10 m, Fig. 1) occurred between both acquisition periods. These resuspension events are not visible in the calculated DOC concentration maps on the right (Fig. 7d).

\section{In situ DOC vs. remotely sensed DOC}

To evaluate the satellite-retrieved DOC concentrations, we compared in situ and ONNS-retrieved DOC concentrations (Fig. 8) using the presented DOC $-a_{\mathrm{CDOM}}(\lambda)$ model (Eq. 7) and investigated the plausibility of the DOC value ranges and the derived spatial patterns (Fig. 7b, c). This evaluation revealed a moderate performance $\left(r^{2}=0.53\right.$, slope of 0.61$)$ (Fig. 8) despite several days' difference in sampling times between satellite and in situ sampling. The use of MERIS full-resolution data revealed a slightly better performance $\left(r^{2}=0.68\right.$, slope of 0.77). However, we preferred the use of reduced-resolution data due to the reported better quality (Hu et al., 2012). This comparison constitutes an evaluation and not a direct validation of the method. The latter is hampered by the lack of matching data and the time offsets between satellite acquisition and in situ sampling dates. The DOC $-a_{\mathrm{CDOM}}(\lambda)$ model presented in this study improved satellite-derived estimates of DOC concentration compared to estimates using the $\mathrm{DOC}-a_{\mathrm{CDOM}}(\lambda)$ relationship reported by Matsuoka et al. (2017) $\left(r^{2}=0.46\right.$, Fig. 8$)$.

To spare in situ data for this performance test, data from LD10 were not used to develop the DOC $-a_{\mathrm{CDOM}}(\lambda)$ model (Eq. 7). The DOC concentrations for NE10 were calculated from in situ $a_{\mathrm{CDOM}}(443)$ measurements using Eq. (7), since no in situ DOC measurements were taken on NE10. These in situ DOC concentrations are therefore not independent but were derived from the DOC- $a_{\mathrm{CDOM}}(443)$ relationship for the entire dataset. However, samples from NE10 were not used for the development of the DOC $-a_{\mathrm{CDOM}}(\lambda)$ relation- 


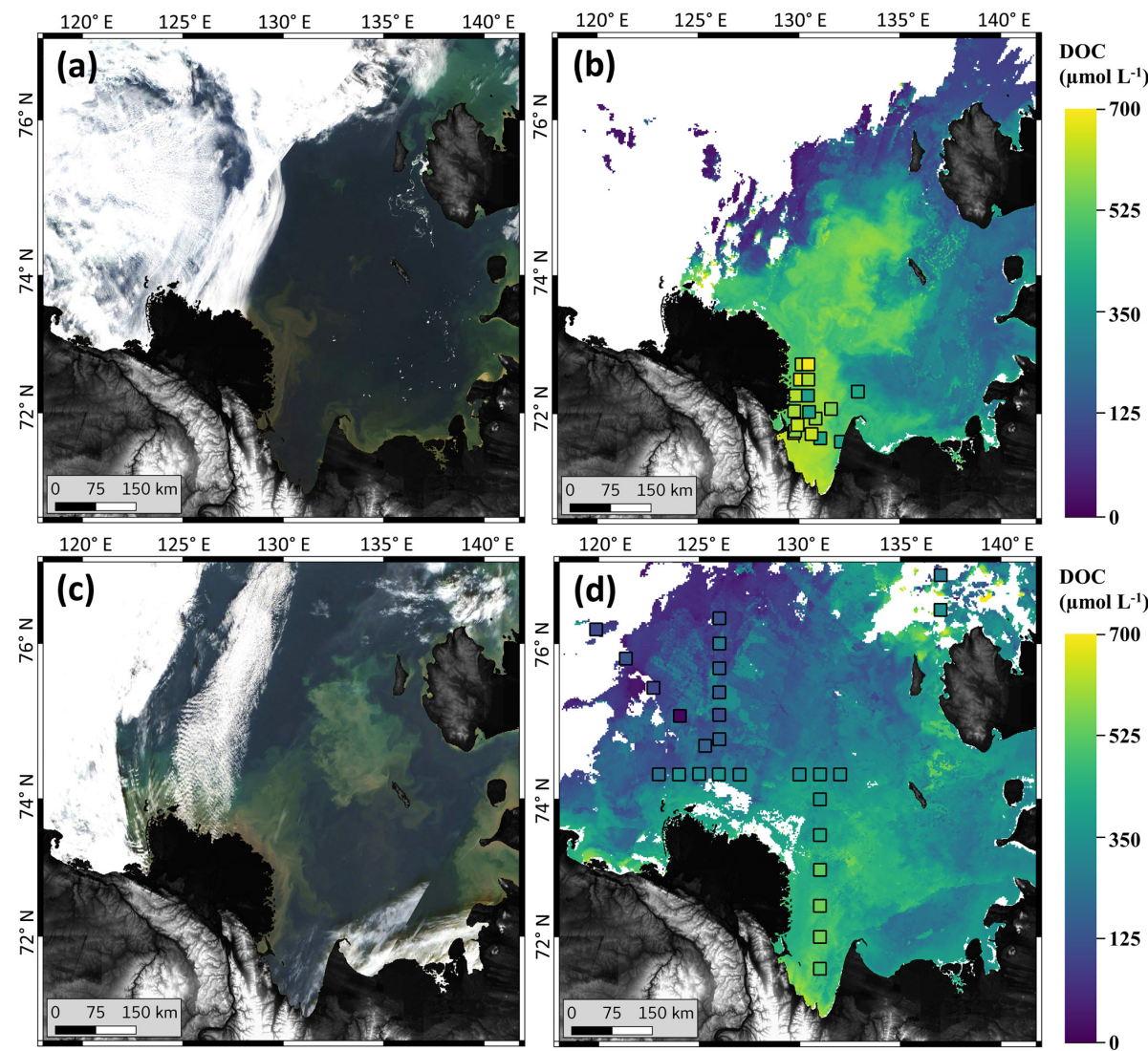

Figure 7. (a) Quasi-true colour image from 5 August 2010. (b) Surface water ONNS-DOC concentration from satellite mosaics from 3 to 5 August 2010. (c) Quasi-true colour image from 7 September 2010. (d) Surface water ONNS-DOC concentration from satellite mosaics from 7 September 2010 and 18 to 20 September 2010. Squares in panels (b) and (d) indicate in situ concentrations with the same colour scale as satellite data.

ship since in situ DOC was missing. We use the data to test the DOC retrieval for a wide range of concentrations. Further validation of the DOC retrieval will require additional in situ datasets collected simultaneously with cloud-free, openwater remote sensing acquisitions by using the MERIS successor OLCI.

\section{Discussion}

\subsection{Sources and modification of DOM in the fluvial-marine transition}

Our results showed that $a_{\mathrm{CDOM}}(443)$ decreases as a function of salinity (Fig. 3), indicating that river water is the main source of CDOM on the Laptev Sea shelf waters and in coastal waters and thus that most CDOM is of terrigenous origin. Despite the tight relationship, some data points deviated from the mixing line in the salinity range from 2 to 24. Deviations from the mixing line can result from combined physical, chemical and biological processes that modify CDOM optical properties (Asmala et al., 2014; Matsuoka et al., 2015, 2017). Helms et al. (2008) and Matsuoka et al. (2012) suggested that higher $a_{\mathrm{CDOM}}(443)$ and lower S350-500 can be used as a proxy indicating that microbial degradation is more important than photodegradation. Indeed, we observed higher $a_{\mathrm{CDOM}}(443)$ associated with lower S350-500 within a similar salinity range (Fig. 3), pointing towards stronger microbial degradation than photodegradation.

Flocculation can also modify CDOM optical properties by removing larger molecules once the river water encounters saline water. However, given the fact that this process occurs at low salinities (0 to 3) (Asmala et al., 2014), flocculation alone cannot explain the deviation of $a_{\mathrm{CDOM}}(443)$ values apart from the mixing line.

S275-295 was strongly correlated with $a_{\mathrm{CDOM}}(443)$ (Fig. 4a), which is mainly associated with the high-content lignin chromophores in our samples (Fichot et al., 2013) and is partly explained by the long exposure of DOM to solar radiation and the resulting photodegradation (Hansen et al., 2016; Helms et al., 2008). Lena River water shows high lignin content and higher proportion of syringyl and vanylphenols relative to p-hydroxyphenols (Amon et al., 2012). Benner and Kaiser (2011) showed that this could 


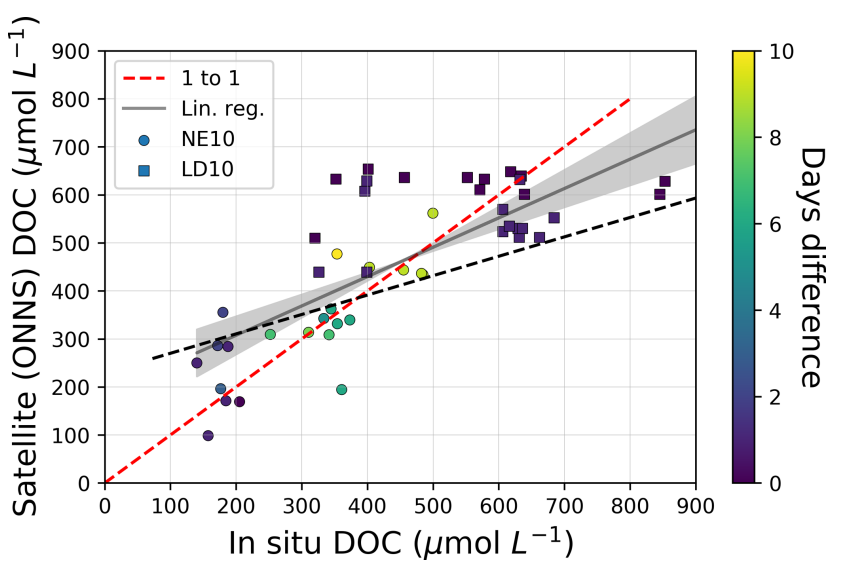

Figure 8. Comparison of in situ DOC and ONNS-derived DOC. The dark grey line shows a linear regression $\left(r^{2}=0.53\right.$, slope of $0.61, n=50)$. The grey area represents the $95 \%$ confidence interval. The red line indicates $1: 1$ correspondence. Day difference (symbol colour) shows the temporal offset between the satellite scene and in situ water sampling. The dashed black line shows the satellite DOC concentration calculated by using the DOC$a_{\mathrm{CDOM}}(443)$ relationship from Matsuoka et al. (2017).

make the DOM more subject to photodegradation, which might supports why such a high correlation was observed.

Compared to the strong relationship between S275-295 and $a_{\mathrm{CDOM}}(443)$, a moderate correlation was observed for S350-500 versus $a_{\mathrm{CDOM}}(443)$ relationship (Fig. 4b), suggesting different degradation mechanisms were involved during the transition from river to coastal and offshore waters. Here, we use S350-500, which is often used in the OCRS community (Babin et al., 2003; Matsuoka et al., 2011, 2012), instead of S350-400, which is the wavelength range suggested by Helms et al. (2008). Note that the correlation between S350-500 and S350-400 is very high ( $r=0.98)$, and thus both slopes can be used. The mean river endmember value of S350-500 at zero salinity was $0.0163 \mathrm{~nm}^{-1}$. This value tends to be lower in the EAO (including Lena River mouth) than in the WAO (Matsuoka et al., 2017; Stedmon et al., 2011). The higher $a_{\mathrm{CDOM}}(443)$ associated with the lower spectral slope observed in our river and coastal waters suggested more aromaticity in waters obtained from the Lena-Laptev region (Stedmon et al., 2011). This was further demonstrated by our higher $a_{\mathrm{CDOM}}^{*}(443)$ (Fig. 4c).

The S350-500 versus $a_{\mathrm{CDOM}}(443)$ relationship showed a moderate but significant negative correlation and most samples were within a terrestrial range (dashed lines, Fig. 4b). The fact that no samples were within the reported ranges of photodegradation for oceanic waters (solid lines, Fig. 4b) suggests that CDOM in coastal waters of the Laptev Sea would have been highly influenced by terrestrial inputs but with the least photodegradation effect compared to that in oceanic waters (Matsuoka et al., 2015, 2017). It is likely that high turbidity and thus less transparent water of coastal re- gions in the Laptev Sea protects DOM from photodegradation. Data points outside of the ranges might indicate either microbial degradation and/or sea-ice melt (Matsuoka et al., 2017). Given the only minor influence of ice melt waters during most of our field campaigns, microbial degradation is more likely for some of our samples, which is consistent with our explanation for deviated samples shown in Fig. 3.

The difference in optical properties of $a_{\mathrm{CDOM}}(\lambda)$ observed between EAO and WAO is possibly caused by geological difference rather than climatic influences (Gordeev et al., 1996). This is partly supported by the chemical characterization of lignin phenols (Amon et al., 2012). Our results showed specificity of optical properties in the Lena River and Laptev Sea and underline the necessity of discussing spectral optical properties when $a_{\mathrm{CDOM}}(443)$ and DOC concentration are estimated in this region.

\subsection{Linking CDOM absorption to dissolved organic carbon concentration}

Previous reported DOC $-a_{\mathrm{CDOM}}(\lambda)$ models such as Walker et al. (2013), Örek et al. (2013) and Mann et al. (2016) for Arctic rivers, Matsuoka et al. (2012) for WAO and Gonçalves-Araujo et al. (2015) for coastal waters are restricted in their use to the water type of samples. Our presented DOC- $a_{\mathrm{CDOM}}(\lambda)$ relationship improves reported models from Mann et al. (2016) and Matsuoka et al. (2017) for the estimation of DOC from $a_{\mathrm{CDOM}}(443)$ in DOC-rich waters in transition zones of river and seawater of the Lena-Laptev region. Matsuoka et al. (2017) provided satellite-retrieved DOC concentration maps for coastal waters of the Lena River Delta region, retrieved with a DOC- $a_{\mathrm{CDOM}}(443)$ relationship developed using a pan-Arctic in situ dataset. However, the retrieved DOC concentrations were likely underestimated compared to in situ measurements in the coastal regions of the Laptev Sea presented in this study. In coastal or $a_{\mathrm{CDOM}}(443)$-rich, river-influenced water, the difference between the two relationships is expected to be highest. Applying the Matsuoka et al. (2017) relationship to $a_{\mathrm{CDOM}}(443)-$ rich waters outside its validity ranges $\left(>3.3 \mathrm{~m}^{-1}\right)$ would result in underestimation of DOC compared to the relationship presented in this study. Taking mean Lena River $a_{\mathrm{CDOM}}(443)$ of $4.1 \mathrm{~m}^{-1}$, which is similar to the highest $a_{\mathrm{CDOM}}(443)$ values in coastal waters, the difference in modelled DOC concentration between both relationships is $186.8 \mu \mathrm{mol} \mathrm{L}^{-1}$. The main reason for this underestimation is likely the lack of near-coastal and river water samples with high DOC for the development of their relationship. This hypothesis was confirmed by testing the relationship of our dataset by removing coastal and river water. This decreased the slope of the fitting model and led to an underestimation of DOC in coastal and river waters (without coastal and river water: slope of 0.617). The slope of the reported fitting model from Matsuoka et al. (2017) is lower (0.448), compared to the fitting model from this study (all samples: slope of 0.664). This dif- 
ference highlights the importance of using a broad concentration range to develop such relationships.

The broad concentration range of the relationship presented here permits the generation of remotely sensed surface DOC concentration maps of the Laptev Sea across the fluvial-marine transition zone using $a_{\mathrm{CDOM}}(443)$. The applicability of this relationship for other Arctic fluvial-marine transition regions (e.g. Yenisei, Ob, Kolyma, Mackenzie) is untested and the relationship may need to be extended with regionally specific data.

Previous studies using $a_{\mathrm{CDOM}}(443)$ often focused on different wavelengths for $a_{\mathrm{CDOM}}(\lambda)$. The shape of the DOC$a_{\mathrm{CDOM}}(\lambda)$ relationship is strongly dependent on the chosen $a_{\mathrm{CDOM}}(\lambda)$ wavelength, whereas DOC- $a_{\mathrm{CDOM}}(350)$ shows a linear relationship, $a_{\mathrm{CDOM}}(443)$ can be better described with a power function (see Eq. 7). Table A1 provides coefficients for selected $a_{\mathrm{CDOM}}(\lambda)$ wavelengths. We encourage the data publication of all available wavelengths for $a_{\mathrm{CDOM}}(\lambda)$ measurements in future studies to enable direct comparisons between studies and regions.

\section{ONNS-derived DOC}

The evaluation of ONNS-derived $a_{\mathrm{CDOM}}(\lambda)^{\text {sat }}$ performed best when tested with in situ data (Table 3 ). Thus, we selected the ONNS-derived $a_{\mathrm{CDOM}}(440)^{\text {sat }}$ to calculate DOC concentration based on the Eq. (7). The evaluation of ONNSderived DOC concentrations showed moderate performance $\left(r^{2}=0.53\right)$. We suggest that the only moderate agreement likely results from rapid movement of near-coastal water fronts. Fluvial-marine transition zones, as in this study area, are characterized by rapidly moving water fronts with large variations in DOC concentration. A spatial shift of a plume between in situ sampling and the satellite acquisition can cause large errors in the match-up performance. All samples from LD10 expedition are located in the near-coastal areas east of the Lena River Delta where rapid movements of water fronts are likely. This could partly explain deviations comparing in situ measurements and the satellite-derived DOC at a given pixel. Taking this into account, the observed agreement shows an adequate retrieval of DOC by satellite using the OCRS ONNS algorithm.

Using satellite-retrieved surface water DOC concentration maps (Fig. 7b, d), we demonstrated rapid changes in DOC concentrations in the Laptev over 1 month in late summer. The rapid DOC decrease can result from a combination of vertical mixing, dilution and microbial and photodegradation of the organic material in the surface water (Fichot et al., 2013; Holmes et al., 2008; Mann et al., 2012). OCRS could potentially be used to monitor the rapid removal of DOM by degradation from surface waters on Arctic shelves.

\subsection{OCRS algorithms in shallow Arctic fluvial-marine transition zones}

We observed specific problems of $a_{\mathrm{CDOM}}(\lambda)^{\text {sat }}$ retrievals for optically complex shallow shelf waters using different OCRS algorithms. The retrieved $a_{\mathrm{CDOM}}(\lambda)^{\text {sat }}$ in shallow waters often shows a co-variation with high TSM, which is a result of high particle backscatter in the water such as sediments or some phytoplankton types. In our study, we observed that most OCRS algorithms show a strong coupling of $a_{\mathrm{CDOM}}(\lambda)^{\mathrm{sat}}$ and TSM in all areas of high sediment concentration (compare Figs. 7 and 9b).

Our study area, the Laptev Sea shelf, is characterized by extremely shallow waters with frequent resuspension of sediments from the seafloor, for example, during storm events. In the Lena River plume, close to the river mouth, where large amounts of TSM and organic matter are transported to the Arctic Ocean, we expect DOC and TSM to co-vary. Once exported by the Lena River, most particles quickly settle to the seafloor, whereas DOM concentration gradually decreases with increasing physical mixing and ongoing degradation. In offshore resuspension areas with very high TSM concentration, DOC and TSM do not necessarily co-vary. Large amounts of terrigenous organic matter can be mineralized on short timescales (about $50 \%$ within a year; Kaiser et al., 2017) and strongly degraded when deposited in sediments (Bröder et al., 2016, 2019; Brüchert et al., 2018).

We observe a strong increase of TSM concentrations in the eastern Laptev Sea in September (Fig. 9b) compared to August (Fig. 9a), which is likely caused by differences in wind speed and resulting wave energy leading to resuspension. During acquisitions in August, wind speeds were very low (NCEP reanalysis mean surface wind speed of $2.06 \mathrm{~m} \mathrm{~s}^{-1}$ for $75^{\circ} \mathrm{N}$ and $132.5^{\circ} \mathrm{E}$ from 1 to 5 August 2010), whereas in September winds were stronger (NCEP reanalysis mean surface wind speed of $6.54 \mathrm{~m} \mathrm{~s}^{-1}$ for $75^{\circ} \mathrm{N}$ and $132.5^{\circ} \mathrm{E}$ from 4 to 20 September 2010). A high TSM concentration in the near-coastal regions around the Lena River Delta, caused by the sediment export by the Lena River, is similar in both mosaics.

The evaluation of OCRS algorithms with in situ data showed the generally good performance of the ONNS and the C2X algorithms (Table 3). However, shallow resuspension areas are not covered by in situ measurements. Thus, the performance of OCRS algorithms cannot be tested in these areas. Whereas the $\mathrm{C} 2 \mathrm{X}$ algorithm derives high $a_{\mathrm{CDOM}}(443)$ in the resuspension areas in the eastern Laptev Sea, the ONNS algorithm derives lower $a_{\mathrm{CDOM}}(440)$ (Fig. 6).

Including all pixels of each scene (Fig. 6), the ONNSderived $a_{\mathrm{CDOM}}(440)$ does not show a linear relationship with TSM concentration (Fig. 10a). However, using only pixels proximal to the Lena River Delta, we observe a correlation $(r=0.68)$, which is caused by the co-variation of TSM and $a_{\mathrm{CDOM}}(440)$ in the river plume. The C2Xderived $a_{\mathrm{CDOM}}(443)$ shows a linear relationship between 

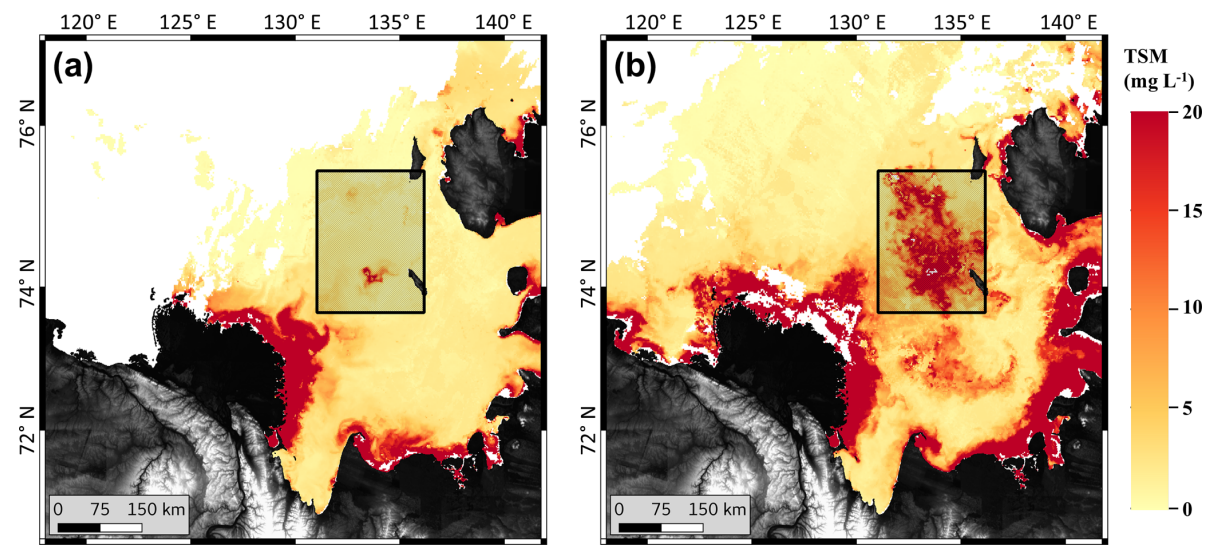

Figure 9. ONNS-derived TSM concentration for satellite mosaics from (a) August 2010 and (b) September 2010. The shallow water area is highlighted by the black square.
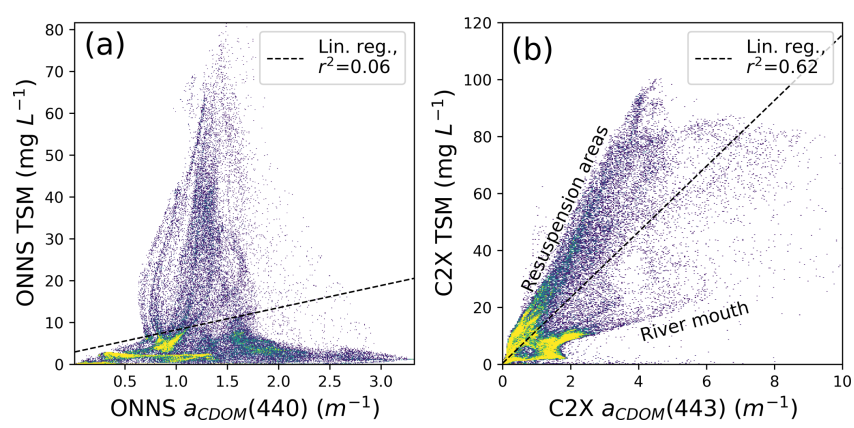

Figure 10. Relationship between (a) ONNS-retrieved $a_{\mathrm{CDOM}}(440)$ and TSM concentration and (b) C2X-retrieved $a_{\mathrm{CDOM}}(440)$ and TSM concentration for the MERIS scene from 7 September 2010. The relationship, using other scenes from September, does not vary significantly (18 September 2010: ONNS $r^{2}=0.22$ and C2X $r^{2}=$ 0.55, 19 September 2010: ONNS $r^{2}=0.23$ and C2X $r^{2}=0.67$, 20 September 2010: ONNS $r^{2}=0.03$ and C2X $r^{2}=0.66$ ).

$a_{\mathrm{CDOM}}(443)$ and TSM $(r=0.79)$. The correlation regimes of the $a_{\mathrm{CDOM}}(443)$ and TSM from river mouth regions and resuspension areas are visible (Fig. 10b). Thus, we show that $\mathrm{C} 2 \mathrm{X}$-derived $a_{\mathrm{CDOM}}(443)$ might vary with TSM. Further confirmation of these satellite-based observations with in situ data is currently not possible due to a lack of in situ data in shallow areas. A partial independence between ONNS-retrieved $a_{\mathrm{CDOM}}(440)$ and TSM is of high importance in shallow Arctic shelf waters, such as the Laptev Sea. Using $\mathrm{C} 2 \mathrm{X}$ algorithm, resuspension events would result in erroneous estimation of $a_{\mathrm{CDOM}}(443)$.

Furthermore, the C2X-derived TSM concentration is substantially higher compared to TSM concentration derived by ONNS (Fig. 10). Örek et al. (2013) and Heim et al. (2014) report TSM concentrations between 10 and $70 \mathrm{mg} \mathrm{L}^{-1}$ for Lena River water and up to $18 \mathrm{mg} \mathrm{L}^{-1}$ in coastal water near the Lena River Delta measured in situ in August 2010. These values are similar to TSM concentrations derived by the
ONNS algorithms but lower than C2X algorithm TSM. Considering overestimation of $\mathrm{C} 2 \mathrm{X}$-derived $a_{\mathrm{CDOM}}(443)$ and TSM compared to in situ data, the use of neural networks trained for a broad range of constituent concentration likely leads to inaccurate results. The combination of neural networks with narrow concentration ranges and a classification into distinct water types (results of classification shown in Fig. C1, Appendix C), as used in the ONNS algorithm, provides more robust and accurate results in regions with a broad range of water types.

\section{Conclusion}

In this study, we demonstrate sources and modification of DOM by analysing $a_{\mathrm{CDOM}}(\lambda)$ characteristics in the fluvialmarine transition zone where the Lena River meets the Laptev Sea. Our results suggest that the $a_{\mathrm{CDOM}}(\lambda)$ spectral slope of S350-500 could be useful to identify and distinguish processes that degrade DOM at this transition. Comparisons of $a_{\mathrm{CDOM}}(\lambda)$ characteristics from this study with reported values from a global dataset and western Arctic waters identify DOM sources as primarily terrigenous.

We demonstrate the strength of a large in situ dataset that covers multiple water types for deriving the relationship between the optical DOM properties and DOC concentration in surface water of the Laptev Sea and Lena Delta region. The broad range of DOC concentrations and $a_{\mathrm{CDOM}}(443)$ from river, coastal and offshore water used to develop this model enables the accurate estimation of DOC by $a_{\mathrm{CDOM}}(\lambda)$ in the transition zone between river and seawater. Comparing satellite-retrieved $a_{\mathrm{CDOM}}(440)$, using the OCRS ONNS algorithm, and in situ $a_{\mathrm{CDOM}}(440)$ demonstrates the performance of the algorithm for these optically complex waters. DOC concentrations calculated from satellite data moderately agreed with in situ DOC measurements $\left(r^{2}=0.53\right)$, demonstrating the applicability of the DOC$a_{\mathrm{CDOM}}(\lambda)$ relationship from our compiled dataset. ONNS- 
derived $a_{\mathrm{CDOM}}(440)$ was found to be independent of the suspended sediment concentration. Thus, resuspension events and resulting sediment-rich backscattering waters seem to have little or no influence on the accuracy of ONNS-derived $a_{\mathrm{CDOM}}(440)$.

The Arctic coastal waters of the Laptev Sea are a key region for the fate of terrestrial DOM and can be monitored synoptically using optical remote sensing with a reasonable accuracy. MERIS-retrieved DOC concentrations presented in this study provide a detailed picture of the spatial distribution of the DOC-rich Lena River water on the Laptev Sea shelf and indicate the rapid changes in the magnitude of DOC concentrations in the surface waters within short time periods. If cloud distribution allows, optical remote sensing provides data of high spatial and temporal resolution to track freshwater pathways in the Arctic Ocean, which are of high interest to the oceanographic community.
Data availability. Data have been made available through PANGAEA: https://doi.pangaea.de/10.1594/PANGAEA.898813 (Juhls et al., 2019). 


\section{Appendix A}

The regression between DOC and $a_{\mathrm{CDOM}}(\lambda)$ was performed for a number of selected wavelengths $(\lambda)$ to enable comparisons with other studies. Table A1 shows regression coefficients dependent on wavelengths.

Table A1. Coefficients selected wavelengths for $a_{\mathrm{CDOM}}(\lambda)$ using the equation $b \cdot a \operatorname{CDOM}(\lambda)^{c}$.

\begin{tabular}{lrr}
\hline$\lambda$ of $a_{\mathrm{CDOM}}(\lambda)$ & $b$ & $c$ \\
\hline 254 & 20.9462548427 & 0.8483590018983822 \\
350 & 97.4272121688 & 0.7260394049434391 \\
375 & 136.577758485 & 0.715114349676763 \\
440 & 322.902097112 & 0.6667788739998305 \\
443 & 333.695151626 & 0.6640204313768572 \\
\hline
\end{tabular}

\section{Appendix B}

Performance of all tested OCRS algorithms is shown in Fig. B1. Whereas ONNS and C2X provide reasonable results close to the $1: 1$ line compared to in situ data, other algorithms (C2R, C2RCC, FUB/WeW) underestimate $a_{\mathrm{CDOM}}(\lambda)^{\text {sat }}$ strongly.

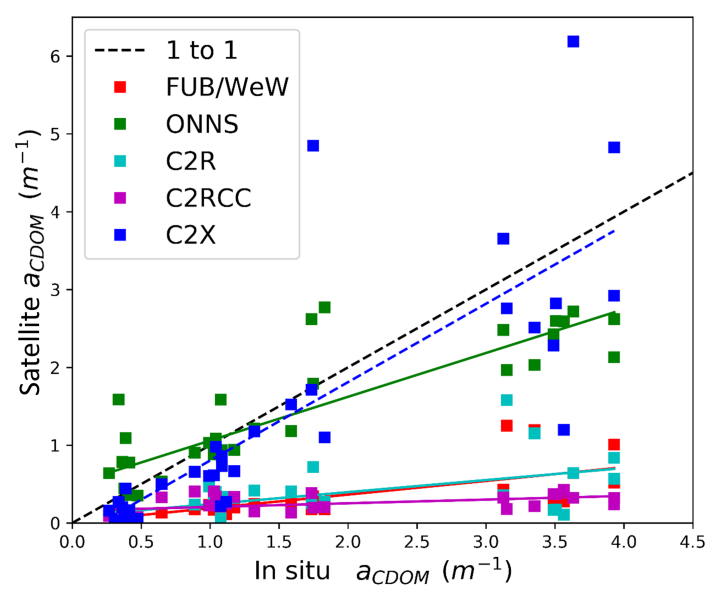

Figure B1. Comparison of in situ $a_{\mathrm{CDOM}}(443)$ or $a_{\mathrm{CDOM}}(440)$ with $a_{\mathrm{CDOM}}(\lambda)^{\text {sat }}$ from different OCRS algorithms. 


\section{Appendix C}

The percentage membership of each pixel is then used to calculate a weighted sum of different neural networks trained for different OWTs. Figure C1 shows the OWTs of the processed scenes from Figs. 6 and 7. It is visible that Lena River plume in the coastal waters was classified as OWT 1 (see "1" in Fig. C1) which indicates optically complex, extreme absorbing and high scattering water. The plume between the Lena Delta and the New Siberian Island is characterized by OWT 5 (see "2" in Fig. C1a, b), which indicated a mixture of high-absorbing and scattering waters. The Lena River water plume with generally Case 2 optically complex waters is sharply delineated to the west, where different water types occur (see "3" in Fig. C1a). Waters west of this plume were classified as OWT 11, displaying Case 1 waters (generally optically deep waters) with a small fraction of absorbing waters.

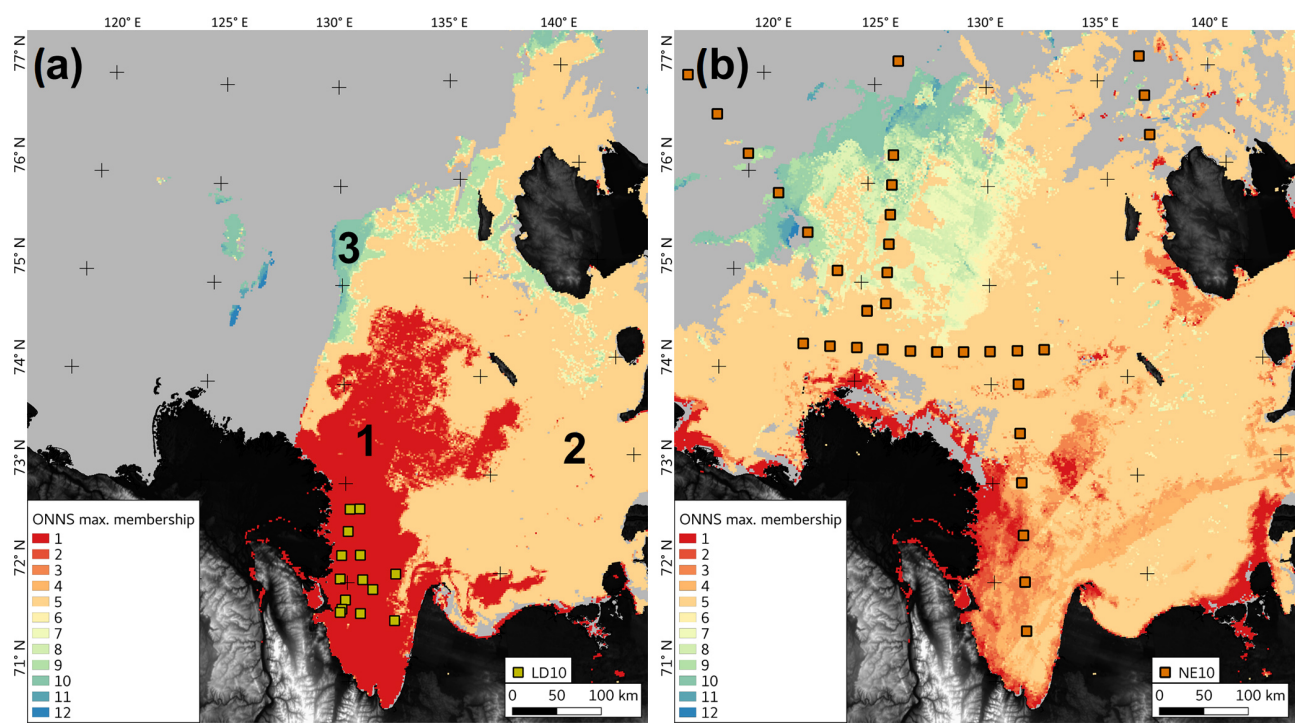

Figure C1. Optical water types from ONNS fuzzy logic classification for (a) average of 3-5 August 2010 and (b) average of 7 and $18-$ 20 September 2010. 
Author contributions. BJ and PPO developed the study design. Field work and data collection for this study was conducted by BJ in all used years, by PPO in 2016 and 2017, by JH in 2010, 2011, 2013 and 2014 and by BH in 2010, 2013, 2014 and 2015. MH processed satellite data with the ONNS algorithm. BJ compiled and processed all presented data and prepared the manuscript with editorial contributions from all co-authors.

Competing interests. The authors declare that they have no conflict of interest.

Acknowledgements. We thank the crews and colleagues aboard the research vessels involved in sampling. We are grateful to the colleagues of the Russian-German Otto Schmidt Laboratory in St. Petersburg for support and accessibility of laboratory instruments for sample analysis. We are eminently thankful to Hajo Krasemann for processing MERIS scenes with the ONNS algorithm and the valuable discussion. NCEP reanalysis data were provided by the NOAA-CIRES Climate Diagnostics Center, Boulder, CO, USA, at https://www.cdc.noaa.gov/ (last access: 4 July 2019). Furthermore, we thank Antje Eulenburg for laboratory analysis of several parameter datasets and Philippe Massicotte for sharing his dataset with us to compare our data. Projects from the EU Horizon 2020 programme (Nunataryuk, grant no. 773421) and from BMBF-NERC's Changing Arctic Ocean programme (CACOON, NERC grant no. NE/R012806/1, BMBF grant no. 03F0806A) supported discussions within a larger group of experts. The authors are grateful to Piotr Kowalczuk and one anonymous reviewer for their constructive comments, which helped to improve the manuscript.

Financial support. This research has been supported by the Geo.X, the Research Network for Geosciences in Berlin and Potsdam (grant no. SO_087_GeoX), the Laptev Sea System (grant no. 03G0833) and the Japan Aerospace Exploration Agency (JAXA) GCOM-C project (grant no. 16RSTK-007867).

We acknowledge support from the Open Access Publication Initiative of Freie Universität Berlin.

Review statement. This paper was edited by Gwenaël Abril and reviewed by Piotr Kowalczuk and one anonymous referee.

\section{References}

Amon, R. M. W., Rinehart, A. J., Duan, S., Louchouarn, P., Prokushkin, A., Guggenberger, G., Bauch, D., Stedmon, C., Raymond, P. A., Holmes, R. M., McClelland, J. W., Peterson, B. J., Walker, S. A., and Zhulidov, A. V.: Dissolved organic matter sources in large Arctic rivers, Geochim. Cosmochim. Ac., 94, 217-237, https://doi.org/10.1016/J.GCA.2012.07.015, 2012.

Antoine, D., Hooker, S. B., Bélanger, S., Matsuoka, A., and Babin, M.: Apparent optical properties of the Canadian Beaufort Sea Part 1: Observational overview and water column relationships,
Biogeosciences, 10, 4493-4509, https://doi.org/10.5194/bg-104493-2013, 2013.

Antoine, D., Babin, M., Berthon, J.-F., Bricaud, A., Gentili, B., Loisel, H., Maritorena, S., and Stramski, D.: Shedding Light on the Sea: André Morel's Legacy to Optical Oceanography, Annu. Rev. Mar. Sci, 6, 1-21, https://doi.org/10.1146/annurev-marine010213-135135, 2014.

Asmala, E., Bowers, D. G., Autio, R., Kaartokallio, H., and Thomas, D. N.: Qualitative changes of riverine dissolved organic matter at low salinities due to flocculation, J. Geophys. Res.-Biogeo., 119, 1919-1933, https://doi.org/10.1002/2014JG002722, 2014.

Babin, M., Stramski, D., Ferrari, G. M., Claustre, H., Bricaud, A., Obolensky, G., and Hoepffner, N.: Variations in the light absorption coefficients of phytoplankton, nonalgal particles, and dissolved organic matter in coastal waters around Europe, J. Geophys. Res., 108, 3211, https://doi.org/10.1029/2001JC000882, 2003.

Bailey, S. W. and Werdell, P. J.: A multi-sensor approach for the on-orbit validation of ocean color satellite data products, Remote Sens. Environ., 102, 12-23, https://doi.org/10.1016/j.rse.2006.01.015, 2006.

Bauch, D., Hölemann, J. A., Nikulina, A., Wegner, C., Janout, M. A., Timokhov, L. A., and Kassens, H.: Correlation of river water and local sea-ice melting on the Laptev Sea shelf (Siberian Arctic), J. Geophys. Res.-Ocean., 118, 550-561, https://doi.org/10.1002/jgrc.20076, 2013.

Benner, R. and Kaiser, K.: Biological and photochemical transformations of amino acids and lignin phenols in riverine dissolved organic matter, Biogeochemistry, 102, 209-222, https://doi.org/10.1007/s10533-010-9435-4, 2011.

Bricaud, A., Morel, A., and Prieur, L.: Absorption by dissolved organic matter of the sea (yellow substance) in the UV and visible domains, Limnol. Oceanogr., 26, 43-53, https://doi.org/10.4319/lo.1981.26.1.0043, 1981.

Brockmann, C., Doerffer, R., Peters, M., Stelzer, K., Embacher, S., and Ruescas, A.: Evolution of the C2RCC Neural Network for Sentinel 2 and 3 for the Retrieval of Ocean Color Products in Normal and Extreme Optically Complex Waters, Living Planet Symp., Vol. 740, available at: https://www.brockmann-consult. de/wp-content/uploads/2017/11/sco1_12brockmann.pdf (last access: 4 July 2019), 2016.

Bröder, L., Tesi, T., Salvadó, J. A., Semiletov, I. P., Dudarev, O. V., and Gustafsson, Ö.: Fate of terrigenous organic matter across the Laptev Sea from the mouth of the Lena River to the deep sea of the Arctic interior, Biogeosciences, 13, 5003-5019, https://doi.org/10.5194/bg-13-5003-2016, 2016.

Bröder, L., Andersson, A., Tesi, T., Semiletov, I., and Gustafsson, Ö.: Quantifying Degradative Loss of Terrigenous Organic Carbon in Surface Sediments Across the Laptev and East Siberian Sea, Global Biogeochem. Cy., 33, 85-99, https://doi.org/10.1029/2018GB005967, 2019.

Brüchert, V., Bröder, L., Sawicka, J. E., Tesi, T., Joye, S. P., Sun, X., Semiletov, I. P., and Samarkin, V. A.: Carbon mineralization in Laptev and East Siberian sea shelf and slope sediment, Biogeosciences, 15, 471-490, https://doi.org/10.5194/bg-15-471-2018, 2018.

Camill, P.: Permafrost Thaw Accelerates in Boreal Peatlands During Late-20th Century Climate Warming, Climatic Change, 68, 135-152, https://doi.org/10.1007/s10584-005-4785-y, 2005. 
Carder, K. L., Steward, R. G., Harvey, G. R. and Ortner, P. B.: Marine humic and fulvic acids?: Their efEcts on remote sensing of ocean chlorophyll, Science, 34, 68-81, 1989.

Cauwet, G. and Sidorov, I.: The biogeochemistry of Lena River: organic carbon and nutrients distribution, Mar. Chem., 53, 211227, https://doi.org/10.1016/0304-4203(95)00090-9, 1996.

Cooper, L. W., Benner, R., McClelland, J. W., Peterson, B. J., Holmes, R. M., Raymond, P. A., Hansell, D. A., Grebmeier, J. M., and Codispoti, L. A.: Linkages among runoff, dissolved organic carbon, and the stable oxygen isotope composition of seawater and other water mass indicators in the Arctic Ocean, J. Geophys. Res.-Biogeo., 110, G02013, https://doi.org/10.1029/2005JG000031, 2005.

Del Vecchio, R. and Blough, N. V: Photobleaching of chromophoric dissolved organic matter in natural waters: kinetics and modeling, Mar. Chem., 78, 231-253, https://doi.org/10.1016/S03044203(02)00036-1, 2002.

Delwart, S., Preusker, R., Bourg, L., Santer, R., Ramon, D., and Fischer, J.: MERIS in-flight spectral calibration, Int. J. Remote Sens., 28, 479-496, https://doi.org/10.1080/01431160600821119, 2007.

Dittmar, T. and Kattner, G.: The biogeochemistry of the river and shelf ecosystem of the Arctic Ocean: a review, Mar. Chem., 83, 103-120, https://doi.org/10.1016/S0304-4203(03)00105-1, 2003.

Doerffer, R. and Schiller, H.: The MERIS Case 2 water algorithm, Int. J. Remote Sens., 28, 517-535, https://doi.org/10.1080/01431160600821127, 2007.

Fasching, C., Behounek, B., Singer, G. A., and Battin, T. J.: Microbial degradation of terrigenous dissolved organic matter and potential consequences for carbon cycling in brown-water streams, Sci. Rep.-UK, 4, 4981, https://doi.org/10.1038/srep04981, 2015.

Fedorova, I., Chetverova, A., Bolshiyanov, D., Makarov, A., Boike, J., Heim, B., Morgenstern, A., Overduin, P. P., Wegner, C., Kashina, V., Eulenburg, A., Dobrotina, E., and Sidorina, I.: Lena Delta hydrology and geochemistry: long-term hydrological data and recent field observations, Biogeosciences, 12, 345-363, https://doi.org/10.5194/bg-12-345-2015, 2015.

Fichot, C. G. and Benner, R.: A novel method to estimate DOC concentrations from CDOM absorption coefficients in coastal waters, Geophys. Res. Lett., 38, L03610, https://doi.org/10.1029/2010GL046152, 2011.

Fichot, C. G. and Benner, R.: The spectral slope coefficient of chromophoric dissolved organic matter (S275-295) as a tracer of terrigenous dissolved organic carbon in riverinfluenced ocean margins, Limnol. Oceanogr., 57, 1453-1466, https://doi.org/10.4319/lo.2012.57.5.1453, 2012.

Fichot, C. G. and Benner, R.: The fate of terrigenous dissolved organic carbon in a river-influenced ocean margin, Global Biogeochem. Cy., 28, 300-318, https://doi.org/10.1002/2013GB004670, 2014.

Fichot, C. G., Kaiser, K., Hooker, S. B., Amon, R. M. W., Babin, M., Bélanger, S., Walker, S. A., and Benner, R.: Pan-Arctic distributions of continental runoff in the Arctic Ocean, Sci. Rep.-UK, 3, 1053, https://doi.org/10.1038/srep01053, 2013.

Freeman, C., Evans, C. D., Monteith, D. T., Reynolds, B., and Fenner, N.: Export of organic carbon from peat soils, Nature, 412, 785-785, https://doi.org/10.1038/35090628, 2001.
Frey, K. E. and Smith, L. C.: Amplified carbon release from vast West Siberian peatlands by 2100 , Geophys. Res. Lett., 32, L09401, https://doi.org/10.1029/2004GL022025, 2005.

Gonçalves-Araujo, R., Stedmon, C. A., Heim, B., Dubinenkov, I., Kraberg, A., Moiseev, D., and Bracher, A.: From Fresh to Marine Waters: Characterization and Fate of Dissolved Organic Matter in the Lena River Delta Region, Siberia, Front. Mar. Sci., 2, 108, https://doi.org/10.3389/fmars.2015.00108, 2015.

Gordeev, V. V., Martin, J. M., Sidorov, I. S., and Sidorova, M. V.: A reassessment of the Eurasian river input of water, sediment, major elements, and nutrients to the Arctic Ocean, Am. J. Sci., 296, 664-691, https://doi.org/10.2475/ajs.296.6.664, 1996.

Granskog, M. A., Stedmon, C. A., Dodd, P. A., Amon, R. M. W., Pavlov, A. K., de Steur, L., and Hansen, E.: Characteristics of colored dissolved organic matter (CDOM) in the Arctic outflow in the Fram Strait: Assessing the changes and fate of terrigenous CDOM in the Arctic Ocean, J. Geophys. Res.-Ocean., 117, C12021, https://doi.org/10.1029/2012JC008075, 2012.

Green, S. A. and Blough, N. V.: Optical absorption and fluorescence properties of chromophoric dissolved organic matter in natural waters, Limnol. Oceanogr., 39, 1903-1916, https://doi.org/10.4319/lo.1994.39.8.1903, 1994.

Guo, W., Stedmon, C. A., Han, Y., Wu, F., Yu, X., and Hu, M.: The conservative and non-conservative behavior of chromophoric dissolved organic matter in Chinese estuarine waters, Mar. Chem., 107, 357-366, https://doi.org/10.1016/J.MARCHEM.2007.03.006, 2007.

Hansen, A. M., Kraus, T. E. C., Pellerin, B. A., Fleck, J. A., Downing, B. D., and Bergamaschi, B. A.: Optical properties of dissolved organic matter (DOM): Effects of biological and photolytic degradation, Limnol. Oceanogr., 61, 1015-1032, https://doi.org/10.1002/lno.10270, 2016.

Heim, B., Abramova, E., Doerffer, R., Günther, F., Hölemann, J., Kraberg, A., Lantuit, H., Loginova, A., Martynov, F., Overduin, P. P., and Wegner, C.: Ocean colour remote sensing in the southern Laptev Sea: evaluation and applications, Biogeosciences, 11, 4191-4210, https://doi.org/10.5194/bg-11-4191-2014, 2014.

Helms, J. R., Stubbins, A., Ritchie, J. D., Minor, E. C., Kieber, D. J., and Mopper, K.: Absorption spectral slopes and slope ratios as indicators of molecular weight, source, and photobleaching of chromophoric dissolved organic matter, Limnol. Oceanogr., 53, 955-969, https://doi.org/10.4319/lo.2008.53.3.0955, 2008.

Helms, J. R., Mao, J., Stubbins, A., Schmidt-Rohr, K., Spencer, R. G. M., Hernes, P. J., and Mopper, K.: Loss of optical and molecular indicators of terrigenous dissolved organic matter during long-term photobleaching, Aquat. Sci., 76, 353-373, https://doi.org/10.1007/s00027-014-0340-0, 2014.

Hieronymi, M.: Spectral band adaptation of ocean color sensors for applicability of the multi-water biogeo-optical algorithm ONNS, Opt. Express, 27, A707, https://doi.org/10.1364/OE.27.00A707, 2019.

Hieronymi, M., Müller, D., and Doerffer, R.: The OLCI Neural Network Swarm (ONNS): A Bio-Geo-Optical Algorithm for Open Ocean and Coastal Waters, Front. Mar. Sci., 4, 140, https://doi.org/10.3389/fmars.2017.00140, 2017.

Hill, V. J.: Impacts of chromophoric dissolved organic material on surface ocean heating in the Chukchi Sea, J. Geophys. Res., 113, C07024, https://doi.org/10.1029/2007JC004119, 2008. 
Holmes, R. M., McClelland, J. W., Raymond, P. A., Frazer, B. B., Peterson, B. J., and Stieglitz, M.: Lability of DOC transported by Alaskan rivers to the Arctic Ocean, Geophys. Res. Lett., 35, L03402, https://doi.org/10.1029/2007GL032837, 2008.

Hu, C., Feng, L., Lee, Z., Davis, C. O., Mannino, A., McClain, C. R., and Franz, B. A.: Dynamic range and sensitivity requirements of satellite ocean color sensors: learning from the past, Appl. Optics, 51, 6045, https://doi.org/10.1364/AO.51.006045, 2012.

Jerlov, N. G.: Optical oceanography, Elsevier Pub. Co., available at: https://www.sciencedirect.com/bookseries/ elsevier-oceanography-series/vol/5 (last access: 4 July 2019), 1968.

Juhls, B., Hölemann, J. A., Heim, B., Overduin, P. P., Gonçalves-Araujo, R., Hieronymi, M., and Fischer, J.: Surface water Dissolved Organic Matter (DOC, CDOM) in the Laptev Sea and Lena River, PANGAEA, https://doi.org/10.1594/PANGAEA.898813, 2019.

Kaiser, K., Benner, R., and Amon, R. M. W.: The fate of terrigenous dissolved organic carbon on the Eurasian shelves and export to the North Atlantic, J. Geophys. Res.-Ocean., 122, 4-22, https://doi.org/10.1002/2016JC012380, 2017.

Kattner, G., Lobbes, J. ., Fitznar, H. ., Engbrodt, R., Nöthig, E.-M., and Lara, R.: Tracing dissolved organic substances and nutrients from the Lena River through Laptev Sea (Arctic), Mar. Chem., 65, 25-39, https://doi.org/10.1016/S03044203(99)00008-0, 1999.

Lobbes, J. M., Fitznar, H. P., and Kattner, G.: Biogeochemical characteristics of dissolved and particulate organic matter in Russian rivers entering the Arctic Ocean, Geochim. Cosmochim. Ac., 64, 2973-2983, https://doi.org/10.1016/S0016-7037(00)004099, 2000.

Makarewicz, A., Kowalczuk, P., Sagan, S., Granskog, M. A., Pavlov, A. K., Zdun, A., Borzycka, K., and Zabłocka, M.: Characteristics of chromophoric and fluorescent dissolved organic matter in the Nordic Seas, Ocean Sci., 14, 543-562, https://doi.org/10.5194/os-14-543-2018, 2018.

Mann, P. J., Davydova, A., Zimov, N., Spencer, R. G. M., Davydov, S., Bulygina, E., Zimov, S., and Holmes, R. M.: Controls on the composition and lability of dissolved organic matter in Siberia's Kolyma River basin, J. Geophys. Res.-Biogeo., 117, G01028, https://doi.org/10.1029/2011JG001798, 2012.

Mann, P. J., Spencer, R. G. M., Hernes, P. J., Six, J., Aiken, G. R., Tank, S. E., McClelland, J. W., Butler, K. D., Dyda, R. Y., and Holmes, R. M.: Pan-Arctic Trends in Terrestrial Dissolved Organic Matter from Optical Measurements, Front. Earth Sci., 4, 25, https://doi.org/10.3389/feart.2016.00025, 2016.

Mannino, A., Russ, M. E., and Hooker, S. B.: Algorithm development and validation for satellite-derived distributions of DOC and CDOM in the U.S. Middle Atlantic Bight, J. Geophys. Res., 113, C07051, https://doi.org/10.1029/2007JC004493, 2008.

Massicotte, P., Asmala, E., Stedmon, C., and Markager, S.: Global distribution of dissolved organic matter along the aquatic continuum: Across rivers, lakes and oceans, Sci. Total Environ., 609, 180-191, https://doi.org/10.1016/J.SCITOTENV.2017.07.076, 2017.

Matsuoka, A., Hill, V., Huot, Y., Babin, M., and Bricaud, A.: Seasonal variability in the light absorption properties of western Arctic waters: Parameterization of the individual components of absorption for ocean color applications, J. Geophys. Res., 116, C02007, https://doi.org/10.1029/2009JC005594, 2011.

Matsuoka, A., Bricaud, A., Benner, R., Para, J., Sempéré, R., Prieur, L., Bélanger, S., and Babin, M.: Tracing the transport of colored dissolved organic matter in water masses of the Southern Beaufort Sea: relationship with hydrographic characteristics, Biogeosciences, 9, 925-940, https://doi.org/10.5194/bg-9-9252012, 2012.

Matsuoka, A., Ortega-Retuerta, E., Bricaud, A., and Babin, M.: Characteristics of colored dissolved organic matter (CDOM) in the Western Arctic Ocean: Relationships with microbial activities, Deep-Sea Res. Pt. II, 118, 44-52, https://doi.org/10.1016/J.DSR2.2015.02.012, 2015.

Matsuoka, A., Boss, E., Babin, M., Karp-Boss, L., Hafez, M., Chekalyuk, A., Proctor, C. W., Werdell, P. J., and Bricaud, A. Pan-Arctic optical characteristics of colored dissolved organic matter: Tracing dissolved organic carbon in changing Arctic waters using satellite ocean color data, Remote Sens. Environ., 200, 89-101, https://doi.org/10.1016/J.RSE.2017.08.009, 2017.

Mobley, C. D., Stramski, D., Bissett, W. P., and Boss, E.: Optical modeling of ocean waters: is the Case 1Case 2 classification still useful?, Oceanography, 17, 60-67, https://doi.org/10.5670/oceanog.2004.48, 2004.

Morel, A. and Prieur, L.: Analysis of variations in ocean color1, Limnol. Oceanogr., 22, 709-722, https://doi.org/10.4319/lo.1977.22.4.0709, 1977.

Nelson, N. B. and Siegel, D. A.: Chromophoric DOM in the Open Ocean, in Biogeochemistry of Marine Dissolved Organic Matter, 547-578, Elsevier, 2002.

Nelson, N. B., Carlson, C. A., and Steinberg, D. K.: Production of chromophoric dissolved organic matter by Sargasso Sea microbes, Mar. Chem., 89, 273-287, https://doi.org/10.1016/j.marchem.2004.02.017, 2004.

Nelson, N. B., Siegel, D. A., Carlson, C. A., Swan, C., Smethie, W. M., and Khatiwala, S.: Hydrography of chromophoric dissolved organic matter in the North Atlantic, Deep-Sea Res. Pt. I, 54, 710-731, https://doi.org/10.1016/J.DSR.2007.02.006, 2007.

Opsahl, S. and Benner, R.: Distribution and cycling of terrigenous dissolved organic matter in the ocean, Nature, 386, 480-482, https://doi.org/10.1038/386480a0, 1997.

Örek, H., Doerffer, R., Röttgers, R., Boersma, M., and Wiltshire, K. H.: Contribution to a bio-optical model for remote sensing of Lena River water, Biogeosciences, 10, 7081-7094, https://doi.org/10.5194/bg-10-7081-2013, 2013.

Raymond, P. A., McClelland, J. W., Holmes, R. M., Zhulidov, A. V., Mull, K., Peterson, B. J., Striegl, R. G., Aiken, G. R., and Gurtovaya, T. Y.: Flux and age of dissolved organic carbon exported to the Arctic Ocean: A carbon isotopic study of the five largest arctic rivers, Global Biogeochem. Cy., 21, GB4011, https://doi.org/10.1029/2007GB002934, 2007.

Schroeder, T. and Schaale, M.: MERIS Case-2 Water Properties Processor, Version 1.0.1, Institute for Space Sciences, Freie Universität Berlin (FUB), available at: http://www.brockmann-consult.de/beam/software/plugins/ FUB-WeW-Water-1.0.1.zip (last access: 4 July 2019), 2005.

Spencer, R. G. M., Aiken, G. R., Butler, K. D., Dornblaser, M. M., Striegl, R. G., and Hernes, P. J.: Utilizing chromophoric dissolved organic matter measurements to derive export and reactivity of dissolved organic carbon exported to the Arctic Ocean: 
A case study of the Yukon River, Alaska, Geophys. Res. Lett., 36, L06401, https://doi.org/10.1029/2008GL036831, 2009.

Stedmon, C. A., Amon, R. M. W., Rinehart, A. J., and Walker, S. A.: The supply and characteristics of colored dissolved organic matter (CDOM) in the Arctic Ocean: Pan Arctic trends and differences, Mar. Chem., 124, 108-118, https://doi.org/10.1016/J.MARCHEM.2010.12.007, 2011.

Syed, T. H., Famiglietti, J. S., Zlotnicki, V., and Rodell, M.: Contemporary estimates of Pan-Arctic freshwater discharge from GRACE and reanalysis, Geophys. Res. Lett., 34, L19404, https://doi.org/10.1029/2007GL031254, 2007.

Thibodeau, B., Bauch, D., Kassens, H., and Timokhov, L. A.: Interannual variations in river water content and distribution over the Laptev Sea between 2007 and 2011: The Arctic Dipole connection, Geophys. Res. Lett., 41, 7237-7244, https://doi.org/10.1002/2014GL061814, 2014.

Vantrepotte, V., Danhiez, F.-P., Loisel, H., Ouillon, S., Mériaux, X., Cauvin, A., and Dessailly, D.: CDOM-DOC relationship in contrasted coastal waters: implication for DOC retrieval from ocean color remote sensing observation, Opt. Express, 23, 33, https://doi.org/10.1364/OE.23.000033, 2015.
Walker, S. A., Amon, R. M. W., and Stedmon, C. A.: Variations in high-latitude riverine fluorescent dissolved organic matter: A comparison of large Arctic rivers, J. Geophys. Res.-Biogeo., 118, 1689-1702, https://doi.org/10.1002/2013JG002320, 2013.

Weishaar, J. L., Aiken, G. R., Bergamaschi, B. A., Fram, M. S., Roger, F., and Mopper, K.: Evaluation of Specific Ultraviolet Absorbance as an Indicator of the Chemical Composition and Reactivity of Dissolved Organic Carbon, Envirvon. Sci. Technol., 37, 4702-4708, https://doi.org/10.1021/ES030360X, 2003.

Yang, D., Kane, D. L., Hinzman, L. D., Zhang, X., Zhang, T., and Ye, H.: Siberian Lena River hydrologic regime and recent change, J. Geophys. Res.-Atmos., 107, ACL 14-1-ACL 14-10, https://doi.org/10.1029/2002JD002542, 2002. 